\title{
Phase relationships between orbital forcing and the composition of air trapped in Antarctic ice cores
}

\author{
Lucie Bazin $^{1, a}$, Amaelle Landais ${ }^{1}$, Emilie Capron ${ }^{2}$, Valérie Masson-Delmotte ${ }^{1}$, Catherine Ritz $^{3}$, Ghislain Picard ${ }^{3}$, \\ Jean Jouzel ${ }^{1}$, Marie Dumont ${ }^{4}$, Markus Leuenberger ${ }^{5}$, and Frédéric Prié ${ }^{1}$ \\ ${ }^{1}$ Laboratoire des Sciences du Climat et de l'Environnement, UMR8212, CEA-CNRS-UVSQ, \\ Orme des Merisiers, Gif sur Yvette, France \\ ${ }^{2}$ British Antarctic Survey, NERC, Cambridge, UK \\ ${ }^{3}$ Laboratoire de Glaciologie et Géophysique de l'Environnement, UMR 5183, \\ Univ. Grenoble Alpes-CNRS, Grenoble, France \\ ${ }^{4}$ Météo-France-CNRS, CNRM-GAME UMR 3589, CEN, Grenoble, France \\ ${ }^{5}$ Climate and Environmental Physics, Physics Institute and Oeschger Center for Climate Change Research, \\ University of Bern, Bern, Switzerland \\ ${ }^{\mathrm{a}}$ now at: School of Earth and Ocean Sciences, Cardiff University, Cardiff CF10 3AT, UK
}

Correspondence to: Lucie Bazin (bazinl@cardiff.ac.uk)

Received: 9 March 2015 - Published in Clim. Past Discuss.: 23 April 2015

Revised: 2 March 2016 - Accepted: 6 March 2016 - Published: 22 March 2016

\begin{abstract}
Orbital tuning is central for ice core chronologies beyond annual layer counting, available back to $60 \mathrm{ka}$ (i.e. thousands of years before 1950) for Greenland ice cores. While several complementary orbital tuning tools have recently been developed using $\delta^{18} \mathrm{O}_{\mathrm{atm}}, \delta \mathrm{O}_{2} / \mathrm{N}_{2}$ and air content with different orbital targets, quantifying their uncertainties remains a challenge. Indeed, the exact processes linking variations of these parameters, measured in the air trapped in ice, to their orbital targets are not yet fully understood. Here, we provide new series of $\delta \mathrm{O}_{2} / \mathrm{N}_{2}$ and $\delta^{18} \mathrm{O}_{\text {atm }}$ data encompassing Marine Isotopic Stage (MIS) 5 (between 100 and $160 \mathrm{ka}$ ) and the oldest part (340-800 ka) of the East Antarctic EPICA Dome C (EDC) ice core. For the first time, the measurements over MIS 5 allow an inter-comparison of $\delta \mathrm{O}_{2} / \mathrm{N}_{2}$ and $\delta^{18} \mathrm{O}_{\text {atm }}$ records from three East Antarctic ice core sites (EDC, Vostok and Dome F). This comparison highlights some site-specific $\delta \mathrm{O}_{2} / \mathrm{N}_{2}$ variations. Such an observation, the evidence of a 100 ka periodicity in the $\delta \mathrm{O}_{2} / \mathrm{N}_{2}$ signal and the difficulty to identify extrema and mid-slopes in $\delta \mathrm{O}_{2} / \mathrm{N}_{2}$ increase the uncertainty associated with the use of $\delta \mathrm{O}_{2} / \mathrm{N}_{2}$ as an orbital tuning tool, now calculated to be $3-4 \mathrm{ka}$. When combining records of $\delta^{18} \mathrm{O}_{\text {atm }}$ and $\delta \mathrm{O}_{2} / \mathrm{N}_{2}$ from Vostok and EDC, we find a loss of orbital signature for these two parameters during periods of minimum eccentricity $(\sim 400 \mathrm{ka}$,
\end{abstract}

$\sim 720-800 \mathrm{ka}$ ). Our data set reveals a time-varying offset between $\delta \mathrm{O}_{2} / \mathrm{N}_{2}$ and $\delta^{18} \mathrm{O}_{\mathrm{atm}}$ records over the last 800 ka that we interpret as variations in the lagged response of $\delta^{18} \mathrm{O}_{\text {atm }}$ to precession. The largest offsets are identified during Terminations II, MIS 8 and MIS 16, corresponding to periods of destabilization of the Northern polar ice sheets. We therefore suggest that the occurrence of Heinrich-like events influences the response of $\delta^{18} \mathrm{O}_{\text {atm }}$ to precession.

\section{Introduction}

Past changes in climate and atmospheric composition are recorded in a variety of ice core proxies. The EPICA Dome C (EDC) ice core has provided the longest available records, and documented glacial-interglacial changes in atmospheric greenhouse gases concentrations (Spahni et al., 2005; Loulergue et al., 2008; Lüthi et al., 2008) and Antarctic surface temperature (Jouzel et al., 2007) back to $800 \mathrm{ka}$ (thousands of years before present, present being AD 1950). Precise and coherent ice core chronologies are critical to establish the sequence of events and to understand these past changes. A specificity of ice core chronologies lies in the requirement to calculate ice and gas chronologies, due to the 
fact that air is trapped several tens of metres below the ice sheet surface. The air is effectively sealed-in at the so-called lock-in depth (LID).

Ice core age scales are usually constructed using ice flow models and different age constraints (Parrenin et al., 2001, 2004, 2007; Buiron et al., 2011). Lemieux-Dudon et al. (2010) have developed a new dating tool (Datice) allowing for the first time to produce an optimized and common chronology for several ice cores from Antarctica and Greenland, over the past $50 \mathrm{ka}$. Using an improved version of this dating tool, as well as an extended set of age constraints, Bazin et al. (2013) and Veres et al. (2013) have established a common chronology (AICC2012 chronology) for four Antarctic ice cores (Vostok; EDC; EPICA Dronning Maud Land, EDML; Talos Dome ice core, TALDICE) and one Greenland ice core (NorthGRIP, NGRIP) extending back to $800 \mathrm{ka}$ for EDC. The accuracy of the AICC2012 chronology has been confirmed recently by an alternative bayesian tool, IceChrono (Parrenin et al., 2015). A key limitation in deep ice core chronologies lies in the lack of absolute age constraints prior to layer counting in NGRIP (for ages older than $60 \mathrm{ka}$, Svensson et al., 2008). Orbital tuning of several parameters measured in the air trapped in ice cores (air content, $\delta \mathrm{O}_{2} / \mathrm{N}_{2}$ and $\delta^{18} \mathrm{O}_{\mathrm{atm}}$ ) has thus played a central role for the construction of the AICC2012 chronology. Orbital tuning permits to attribute ages deduced from the comparison of the integrated summer insolation, summer solstice insolation or precession variations to their observed counterparts in air content, $\delta \mathrm{O}_{2} / \mathrm{N}_{2}$ or $\delta^{18} \mathrm{O}_{\text {atm }}$ respectively, with acceptable uncertainties.

Orbital tuning is commonly applied to deep sea cores, using the orbital properties of benthic foraminifera $\delta^{18} \mathrm{O}$ records, which are primarily related to changes in ice volume (Imbrie and Imbrie, 1980). The most closely related ice core parameter is $\delta^{18} \mathrm{O}_{\mathrm{atm}}, \delta^{18} \mathrm{O}$ of atmospheric $\mathrm{O}_{2}$. Ice core records of $\delta^{18} \mathrm{O}_{\text {atm }}$ are strongly correlated with variations of insolation in the precession band, with a lag assumed to be $\sim 5-6 \mathrm{ka}$ as established for the last termination (glacial-interglacial transition, Bender et al., 1994; Jouzel et al., 1996; Petit et al., 1999; Shackleton et al., 2000; Dreyfus et al., 2007). The modulation of $\delta^{18} \mathrm{O}_{\mathrm{atm}}$ by precession operates through the biosphere productivity and changes in low-latitude water cycle (Bender et al., 1994; Malaizé et al., 1999; Wang et al., 2008; Severinghaus et al., 2009; Landais et al., 2007, 2010). The significant time offset between precession and $\delta^{18} \mathrm{O}_{\text {atm }}$ variations is not straightforward to explain. It partly depends on the 1-2 ka residence time of $\mathrm{O}_{2}$ in the atmosphere and on the complex response of the biosphere productivity and the tropical water cycle to precession changes. Caley et al. (2011) have shown lags of several thousand years between the responses of Indian and Asian monsoon systems and orbital forcing over the last $40 \mathrm{ka}$. Moreover, variations of $\delta^{18} \mathrm{O}_{\mathrm{atm}}$ are not only affected by the response to orbital forcing, but also by the millennial-scale climate variability (Severinghaus et al., 2009; Landais et al.,
2007). During Terminations I and II, $\delta^{18} \mathrm{O}_{\text {atm }}$ maxima have been linked to Heinrich stadials 1 and 11 (Landais et al., 2013). Because of these complex interactions, the lag between $\delta^{18} \mathrm{O}_{\mathrm{atm}}$ and precession should vary with time (Leuenberger, 1997; Jouzel et al., 2002). However, for dating purposes, this lag has been assumed to be constant with an uncertainty of a quarter of a precession cycle (6 ka; Jouzel et al., 1996; Parrenin et al., 2001, 2007; Dreyfus et al., 2007).

Additionally, two other ice core parameters, the air content and the $\delta \mathrm{O}_{2} / \mathrm{N}_{2}$ ratio, have also been used for orbital tuning, associated with a completely different underlying mechanism. The air content and $\delta \mathrm{O}_{2} / \mathrm{N}_{2}$ measured in the air trapped in ice cores are controlled by the enclosure process near the close-off depth (depth of closure of ice interstices and formation of air bubbles). At this depth, a depletion of the $\mathrm{O}_{2} / \mathrm{N}_{2}$ ratio compared to the atmospheric ratio is observed and attributed to the smaller size of $\mathrm{O}_{2}$ molecules compared to $\mathrm{N}_{2}$ ones (Battle et al., 1996; Huber et al., 2006; Severinghaus and Battle, 2006). It is expected that the entrapment process and the associated $\mathrm{O}_{2}$ effusion or permeation effects are linked to the physical properties of snow at this depth. Because snow metamorphism is very strong at the surface of the ice sheet in summer (Town et al., 2008; Picard et al., 2012; Libois et al., 2014), snow physical properties are expected to be driven by local summer insolation. Records of $\delta \mathrm{O}_{2} / \mathrm{N}_{2}$ and air content measured at Vostok, Dome F and EDC indeed depict variability at orbital frequencies, which appears in phase with local summer insolation (Bender, 2002; Kawamura et al., 2007; Raynaud et al., 2007; Lipenkov et al., 2011; Landais et al., 2012).

In summary, $\delta^{18} \mathrm{O}_{\text {atm }}$ provides a relationship between the gas phase age and orbital forcing, due to changes in atmospheric composition driven by changes in low-latitude hydrological cycle and biosphere productivity. Air content and $\delta \mathrm{O}_{2} / \mathrm{N}_{2}$ provide a relationship between the ice phase age and local insolation, due to the impact of snow metamorphism on air trapping processes. These three dating tools have limitations as detailed below.

$\delta^{18} \mathrm{O}_{\text {atm }}$ is a well-mixed atmospheric signal, allowing synchronization of different ice core records. It also has the potential to link ice cores with climate records from other latitudes (e.g. global ice volume, low-latitude hydrological cycle and biosphere productivity). However, due to the numerous and complex processes affecting the $\delta^{18} \mathrm{O}_{\text {atm }}$, this orbital dating tool is generally associated with an uncertainty of $6 \mathrm{ka}$. An important challenge to progress on chronological issues is to estimate the variations of the lag between $\delta^{18} \mathrm{O}_{\mathrm{atm}}$ and precession over the last eight glacial-interglacial cycles.

Contrary to $\delta^{18} \mathrm{O}_{\text {atm }}, \delta \mathrm{O}_{2} / \mathrm{N}_{2}$ and air content are not influenced by remote climate-driven signals such as low-latitude hydrological cycle or Northern Hemisphere land ice volume. Fujita et al. (2009) proposed a model to explain both total air content (effusion effect) and $\delta \mathrm{O}_{2} / \mathrm{N}_{2}$ (permeation effect) variations. This model is based on the different densification rates of layers affected by strong surface metamorphism and 
layers affected by low surface metamorphism. The surface metamorphism is stronger than in the rest of the firn, owing to the higher temperature (in summer) and higher temperature gradient (Libois et al., 2014). Thus, the impact of the different component of the surface energy budget (air temperature, snow albedo, penetration depth of solar radiation, ...) is then conserved down to the close-off depth. However, in addition to the influence of the surface snow metamorphism on snow and firn layering, strong modifications of layering and microstructure are also observed at several tenths of metres below the surface (Hörhold et al., 2012). It has been suggested that the pore structure at close-off, and hence potentially the $\delta \mathrm{O}_{2} / \mathrm{N}_{2}$ and air content, is also affected by changes in dust load (Freitag et al., 2013). Moreover, the direct effect of accumulation rate on $\delta \mathrm{O}_{2} / \mathrm{N}_{2}$ and air content cannot be neglected (Hutterli et al., 2010): accumulation rate will indeed have an influence on the permeation mechanism proposed by Fujita et al. (2009) through (1) the increase of the pressure difference between open and closed bubbles near the closeoff and (2) the increase of the depth of the non-diffusive zone at the bottom of the firn (Witrant et al., 2012). Finally, while Suwa and Bender (2008a) have confirmed the orbital signature in the $\delta \mathrm{O}_{2} / \mathrm{N}_{2}$ record from the Greenland core GISP2 as already observed in Antarctic records, they have also observed an additional millennial-scale variability component. The millennial variability of GISP $2 \delta \mathrm{O}_{2} / \mathrm{N}_{2}$ record is in phase with accumulation rate and temperature changes associated with the Dansgaard-Oeschger events, suggesting a non-negligible influence of local temperature or accumulation on $\delta \mathrm{O}_{2} / \mathrm{N}_{2}$ variations. In summary, the direct link classically assumed between summer solstice insolation and $\delta \mathrm{O}_{2} / \mathrm{N}_{2}$ variations is therefore complicated by the possible influence of temperature, accumulation, dust load and surface energy budget.

The limitations associated with the use of $\delta \mathrm{O}_{2} / \mathrm{N}_{2}$, $\delta^{18} \mathrm{O}_{\text {atm }}$ and air content have recently motivated a first assessment of the coherency between the different orbital dating tools in ice cores. Indeed, in the framework of the AICC2012 chronology construction Bazin et al. (2013) took advantage of available records of $\delta \mathrm{O}_{2} / \mathrm{N}_{2}$, air content and $\delta^{18} \mathrm{O}_{\text {atm }}$ over the period $100-400 \mathrm{ka}$ of the Vostok ice core (Petit et al., 1999; Bender, 2002; Suwa and Bender, 2008b; Lipenkov et al., 2011). Bazin et al. (2013) showed that the final chronology was the same using one or the other orbital markers with uncertainties of up to 7, 4 and $6 \mathrm{ka}$ for air content, $\delta \mathrm{O}_{2} / \mathrm{N}_{2}$ and $\delta^{18} \mathrm{O}_{\text {atm }}$ respectively. However, this first conclusion was restricted to one single ice core covering only the last $400 \mathrm{ka}$. The large uncertainties associated with the different orbital age markers in this case were partly due to the low resolution of the existing records and to the poor quality of the $\delta \mathrm{O}_{2} / \mathrm{N}_{2}$ data, affected by gas loss (Landais et al., 2012). Gas loss, which occurs through microcracks and/or through molecular diffusion during coring and ice core storage at warm temperature (typically freezers at -20 or $-25^{\circ} \mathrm{C}$ ), favours the loss of $\mathrm{O}_{2}$ and alters the original $\delta \mathrm{O}_{2} / \mathrm{N}_{2}$ signal (Kawamura et al., 2007; Bender et al., 1995; Ikeda-Fukazawa et al., 2005). Drifts in $\delta \mathrm{O}_{2} / \mathrm{N}_{2}$ have been shown to be related to storage duration (Kawamura et al., 2007) and must be corrected prior to the use of the data.

Our current understanding of these three orbital dating tools motivates further comparison of $\delta \mathrm{O}_{2} / \mathrm{N}_{2}$ and $\delta^{18} \mathrm{O}_{\mathrm{atm}}$ records, obtained (i) at high temporal resolution, (ii) from different East Antarctic ice cores, (iii) under different orbital and climatic contexts and (iv) on ice stored at a very cold temperature $\left(-50^{\circ} \mathrm{C}\right)$ to avoid gas loss. In order to complement existing records from the Vostok and Dome F ice cores, we have performed new measurements on the long EDC ice core, for which only parts of the current $\delta \mathrm{O}_{2} / \mathrm{N}_{2}$ record were obtained from samples of well-conserved ice $\left(-50^{\circ} \mathrm{C}\right)$ (Landais et al., 2012).

For this purpose, we have performed new measurements of $\delta^{18} \mathrm{O}_{\mathrm{atm}}$ and $\delta \mathrm{O}_{2} / \mathrm{N}_{2}$ on ice stored at $-50{ }^{\circ} \mathrm{C}$ (i.e. nonaffected by gas loss) on the EDC ice core over Marine Isotope Stage (MIS) 5 and between 340 and $800 \mathrm{ka}$. Section 2 describes the new measurements on the EDC ice core complementing previous data (Dreyfus et al., 2007, 2008; Landais et al., 2012; Bazin et al., 2013; Landais et al., 2013). Section 3 is dedicated to the analyses of the data sets, the inter-comparison of Vostok, Dome F and EDC data over MIS 5, as well as an investigation of the time delay between $\delta \mathrm{O}_{2} / \mathrm{N}_{2}$ and $\delta^{18} \mathrm{O}_{\mathrm{atm}}$ variations for the last $800 \mathrm{ka}$ and their implications for orbital tuning. The records of $\delta^{18} \mathrm{O}_{\mathrm{atm}}$ and $\delta \mathrm{O}_{2} / \mathrm{N}_{2}$ enable us to check the coherency of these parameters for orbital tuning and to provide recommendations for their use for ice core chronology building.

\section{Analytical method and measurements}

The measurements of the isotopic composition of air trapped in well-conserved ice from EDC were performed at LSCE. The samples were cut in Antarctica in the archive trench at $-40^{\circ} \mathrm{C}$ maximum, and then kept at $-50^{\circ} \mathrm{C}$ during transportation and storage. Measurements were performed only a few months after their transportation from Antarctica. To prevent any contamination from exchanges with ambient air due to micro-cracks, we shave off $3-5 \mathrm{~mm}$ of ice on each face of the sample ( $\sim 10 \mathrm{~g}$ of ice). Two different air extraction methods have been used, either a manual or a semi-automatic line.

The manual method consists of a melt-refreeze technique (Sowers et al., 1989; Landais et al., 2003) for extracting the air trapped in the ice samples. The sample is placed in a cold flask and then the air in the flask is pumped. The trapped air is extracted by melting and refreezing the sample and is then cryogenically transferred in a stainless-steel tube immersed in liquid helium.

For the semi-automatic extraction line, we proceed with two exterior air samples and three ice samples with duplicates each day. The samples are placed in cold flasks and the air in the flasks is pumped; the air trapped in ice is extracted by melting of the samples and left at room temperature dur- 


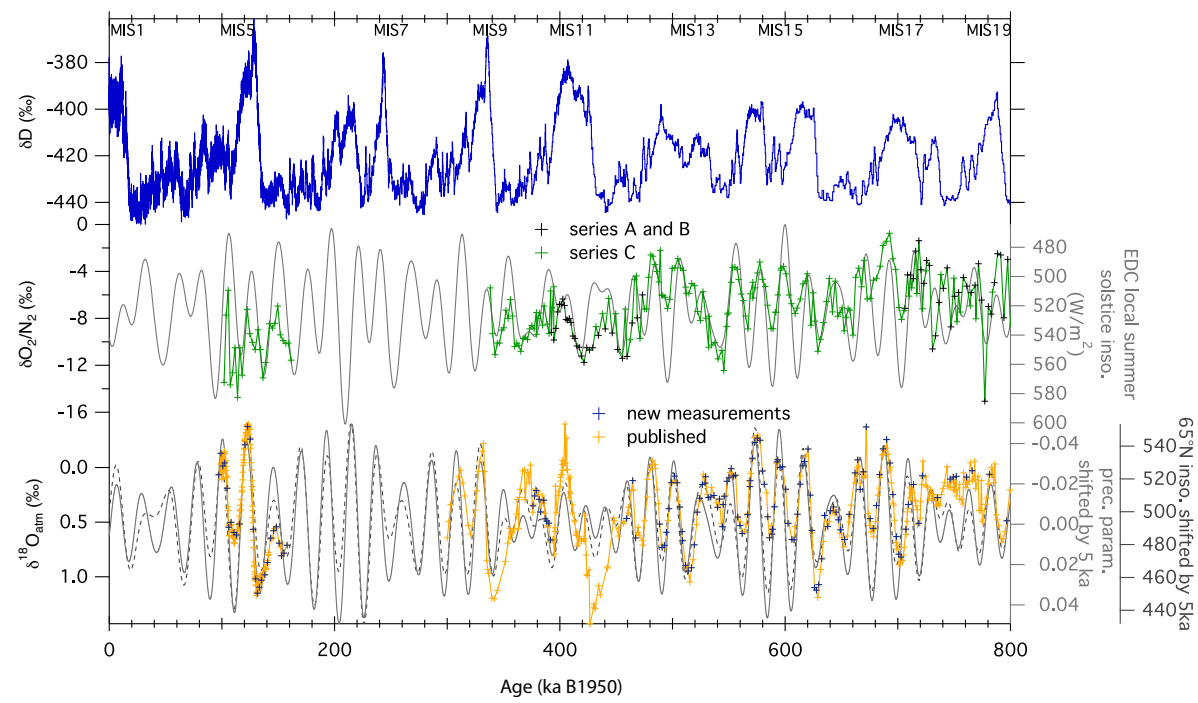

Figure 1. Top: EDC ice core record of water stable isotopes ( $\delta \mathrm{D}$, Jouzel et al., 2007). Middle: EDC record of $\delta \mathrm{O}_{2} / \mathrm{N}_{2}$ (black: Landais et al. (2012), green: this study) and local summer solstice insolation (grey, reversed axis). Bottom: EDC record of $\delta^{18} \mathrm{O}_{\mathrm{atm}}(\mathrm{reversed} \mathrm{vertical} \mathrm{scale)}$ (orange: Dreyfus et al. (2007, 2008); Landais et al. (2013), blue: this study), precession parameter (grey, reversed axis) and $65^{\circ} \mathrm{N}$ summer solstice insolation (dashed grey) both shifted by $5 \mathrm{ka}$. All EDC records are presented on the AICC2012 chronology (Bazin et al., 2013; Veres et al., 2013). The orbital parameters are calculated using the Laskar et al. (2004) solution, with the Analyseries software (Paillard et al., 1996).

ing $1 \mathrm{~h}$ minimum. The air samples are then transferred one at a time through $\mathrm{CO}_{2}$ and water vapour traps before being cryogenically trapped into a manifold immersed in liquid helium. An inter-comparison of the two extraction lines has been conducted using air extracted from NGRIP ice samples. No bias is observed between the two analytical extraction methods.

After a waiting time of $40 \mathrm{~min}$, allowing the tubes to reach room temperature, measurements are performed with a dual inlet Delta V plus (Thermo Electron Corporation) mass spectrometer. A classical run is composed of 16 measurements of the sample in parallel with 16 measurements of a standard of dried exterior air. We simultaneously measure $\delta^{18} \mathrm{O}, \delta \mathrm{O}_{2} / \mathrm{N}_{2}$ and $\delta^{15} \mathrm{~N}$. The data are then calibrated against the mean exterior air values and corrected for mass interferences following the standard methodologies (Severinghaus et al., 2001; Landais et al., 2003).

We were able to replicate 152 samples over 189 depth levels due to the small size of samples. The $\delta \mathrm{O}_{2} / \mathrm{N}_{2}$ and ${ }^{18} \mathrm{O}$ measurements are corrected for gravitational fractionation using the following equations:

$$
\begin{aligned}
& \delta^{18} \mathrm{O}_{\text {atm }}=\delta^{18} \mathrm{O}-2 \cdot \delta^{15} \mathrm{~N} \\
& \delta \mathrm{O}_{2} / \mathrm{N}_{2}=\delta \mathrm{O}_{2} / \mathrm{N}_{2 \text { raw }}-4 \cdot \delta^{15} \mathrm{~N} .
\end{aligned}
$$

The final precision (pooled standard deviation) for our new set of data is $0.02 \%$ or $\delta^{18} \mathrm{O}_{\text {atm }}$ and $0.77 \%$ for $\delta \mathrm{O}_{2} / \mathrm{N}_{2}$.

\section{Results and discussion}

Figure 1 shows the full EDC $\delta^{18} \mathrm{O}_{\mathrm{atm}}$ data set, which has a mean temporal resolution of $1.1 \mathrm{ka}$ thanks to our new data completing the records of Dreyfus et al. (2007, 2008), Bazin et al. (2013) between 300 and $800 \mathrm{ka}$ and Landais et al. (2013) over MIS 5. The data depict variations that coincide with those of precession, together with larger changes associated with glacial terminations. The good overall agreement between variations in precession and in the $\delta^{18} \mathrm{O}_{\mathrm{atm}}$ signal only breaks during periods of low eccentricity: between 350 and $450 \mathrm{ka}$ (MIS12-11-10) and around 700 to $800 \mathrm{ka}$. As already observed by Dreyfus et al. (2007), our new data illustrate that precession-driven variations in $\delta^{18} \mathrm{O}_{\mathrm{atm}}$ are reduced during these periods of low eccentricity. Moreover, with the addition of our new data, the tuning performed by Dreyfus et al. (2007) between 530 and $550 \mathrm{ka}$ is not as straightforward as previously presented. Still, the new ages deduced from $\delta^{18} \mathrm{O}_{\text {atm }}$ orbital tuning stay within the original uncertainty associated with this dating method and have no significant impact on the chronology construction.

The spectral analysis of the new $\delta^{18} \mathrm{O}_{\mathrm{atm}}$ record on the AICC2012 chronology gives a power spectrum consistent with previous studies for EDC between 400 and $800 \mathrm{ka}$ (Dreyfus et al., 2007, on EDC 2 and EDC 3 chronologies) as well as Vostok and Dome F records between 0 and $400 \mathrm{ka}$ (GT4 - Petit et al. (1999) and DFO-2006 - Kawamura et al. (2007) respectively). Since the construction of the timescale AICC2012 partly relies on $\delta^{18} \mathrm{O}_{\text {atm }}$ orbital tuning, no addi- 
tional information from the spectral analysis over the orbital frequencies can be expected.

Our new measurements on well-conserved ice allow us to establish a record of $\delta \mathrm{O}_{2} / \mathrm{N}_{2}$ covering MIS 5 and the period between 340 and $800 \mathrm{ka}$ (Fig. 1). Series A (392-473 ka) and B (706-800 ka) were measured in 2007-2008 (Landais et al., 2012) and are complemented by our new set of data (Series C). The mean temporal resolution of the complete $\delta \mathrm{O}_{2} / \mathrm{N}_{2}$ record is $2.37 \mathrm{ka}$ over MIS 5 and $2.08 \mathrm{ka}$ for the 340-800 ka period. The pooled standard deviations of each data set vary between 0.3 and $1 \%$ (A: $0.32 \%$, B: $1.03 \%$; C: $0.77 \%$ ).

When compared with the previous $\delta \mathrm{O}_{2} / \mathrm{N}_{2}$ record of EDC affected by gas loss (Landais et al., 2012), our data show the same timing of $\delta \mathrm{O}_{2} / \mathrm{N}_{2}$ variations that coincide with those of local summer solstice insolation at Dome C (Appendix A). However, the relative strengths of minima and maxima of $\delta \mathrm{O}_{2} / \mathrm{N}_{2}$ do not scale with those of summer insolation. Large amplitudes of summer insolation cycles are associated with relatively small amplitudes of the corresponding cycles in $\delta \mathrm{O}_{2} / \mathrm{N}_{2}$ and vice versa (Fig. 1). Moreover, only $13 \%$ of the variance of the raw $\delta \mathrm{O}_{2} / \mathrm{N}_{2}$ data are explained by summer solstice insolation. Finally, the new $\delta \mathrm{O}_{2} / \mathrm{N}_{2}$ record reveals an overall decreasing trend over the last $800 \mathrm{ka}$ at EDC $\left(0.79 \pm 0.08 \%\right.$ o $\left.100 \mathrm{ka}^{-1}\right)$, confirming the observations of Landais et al. (2012) on their composite curve (Appendix A). This decreasing trend has already been identified for the last $400 \mathrm{ka}$ at Vostok $\left(0.56 \pm 0.33 \% \circ 100 \mathrm{ka}^{-1}\right)$ and $360 \mathrm{ka}$ at Dome $\mathrm{F}\left(0.56 \pm 0.28 \% 100 \mathrm{ka}^{-1}\right)$. We conclude that the long-term decreasing trend of $\delta \mathrm{O}_{2} / \mathrm{N}_{2}$ with time is not an artifact due to the gas loss correction, even if it may still be linked to the preservation of air with depth in the different ice cores. Long-term changes in the enclosing process or modification in the atmospheric ratio $\mathrm{O}_{2} / \mathrm{N}_{2}$ can be evoked.

The spectral analysis of the new EDC $\delta \mathrm{O}_{2} / \mathrm{N}_{2}$ record between 340 and $800 \mathrm{ka}$ (Fig. 2) depicts peaks corresponding to the precession and obliquity bands (19-23 and $41 \mathrm{ka})$, together with a $100 \mathrm{ka}$ periodicity. This $100 \mathrm{ka}$ period was neither observed in $\delta \mathrm{O}_{2} / \mathrm{N}_{2}$ records from other Antarctic ice cores (Bender, 2002; Kawamura et al., 2007) nor in the EDC composite record of Landais et al. (2012).

The $100 \mathrm{ka}$ peak is also absent from the power spectrum of summer solstice insolation, independently of the time window considered (Fig. 2). The $100 \mathrm{ka}$ signal in $\delta \mathrm{O}_{2} / \mathrm{N}_{2}$, most strongly imprinted between 400 and $700 \mathrm{ka}$, arises from pronounced minima in the $\delta \mathrm{O}_{2} / \mathrm{N}_{2}$ record at 450, 550 and $650 \mathrm{ka}$. These minima occur during glacial periods characterized by low eccentricity and therefore coincide with local insolation minima (Fig. 1). The $100 \mathrm{ka}$ periodicity identified in the EDC $\delta \mathrm{O}_{2} / \mathrm{N}_{2}$ record between 340 and $800 \mathrm{ka}$, and absent from the other records spanning 0-400 ka, may thus arise from a reduced influence of precession-driven insolation changes on snow metamorphism during eccentricity minima, similarly to the reduced precession-driven signal in $\delta^{18} \mathrm{O}_{\mathrm{atm}}$. The weakening of the insolation influence would

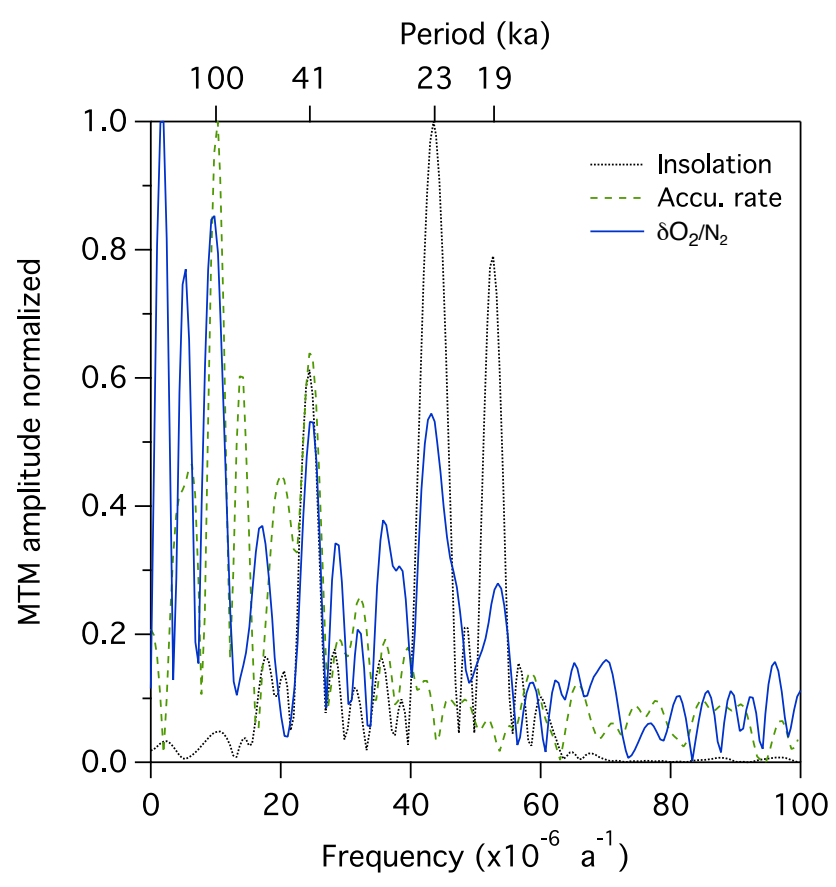

Figure 2. Spectral analysis using the multi-taper method with an interpolation step of $2 \mathrm{ka}$ for $\delta \mathrm{O}_{2} / \mathrm{N}_{2}$ between $340-800 \mathrm{ka}$, obtained with Analyseries (Paillard et al., 1996). Amplitudes are normalized by the maximum value of each series. The $\delta \mathrm{O}_{2} / \mathrm{N}_{2}$ spectral analysis is presented in blue and compared with the spectral analyses of local summer solstice insolation (grey) and AICC2012 accumulation rate (dashed green). Periods corresponding to significant peaks ( $F$ test $>$ $90 \%$ ) are indicated on the upper horizontal axis.

leave room for other factors to impact the $\mathrm{EDC} \delta \mathrm{O}_{2} / \mathrm{N}_{2}$ such as local climatic parameters. Indeed, records of local climate (e.g. water stable isotopes and inferred changes in local temperature and accumulation rate, dust) exhibit a strong peak at $100 \mathrm{ka}$, characteristic of glacial-interglacial cycles (Fig. 2, Masson-Delmotte et al., 2010; Lambert et al., 2008).

\subsection{MIS 5 Antarctic inter-comparison}

Our EDC $\delta \mathrm{O}_{2} / \mathrm{N}_{2}$ record displays variability in the precession and obliquity ranges, as well as minima and maxima that highlight clear similarities with local summer insolation. However, neither the modulation in amplitude nor the $100 \mathrm{ka}$ signal are related to local summer insolation, pointing to other local parameters affecting the firnification processes. Potential candidates that may imprint on $\delta \mathrm{O}_{2} / \mathrm{N}_{2}$ with a $100 \mathrm{ka}$ period would be changes in temperature, accumulation rate, firn dust content or component of the surface energy budget that may affect the snow metamorphism such as wind, albedo or solar radiation penetration depth. The influence of local changes in temperature and accumulation on the $\delta \mathrm{O}_{2} / \mathrm{N}_{2}$ signal is supported by observations of millennialscale variability of $\delta \mathrm{O}_{2} / \mathrm{N}_{2}$ on the GISP2 ice core (Suwa and Bender, 2008a). While variations in summer solstice in- 
Table 1. Summary of present day local conditions at Vostok, Dome F and EDC (Masson-Delmotte et al., 2011; Kawamura et al., 2007; Landais et al., 2012; Lefebvre et al., 2012, this study).

\begin{tabular}{lccccccc}
\hline Site & $\begin{array}{c}\text { Lat. } \\
\text { Long. }\end{array}$ & $\begin{array}{c}\text { Elevation } \\
\text { (m a.s.1.) }\end{array}$ & $\begin{array}{c}\text { No. of days } \\
\text { after 21 Dec } \\
\text { for max temp. }\end{array}$ & $\begin{array}{c}\text { Mean } \\
\text { albedo }\end{array}$ & $\begin{array}{c}\text { Accu. rate } \\
(\mathrm{cm} \text { weq yr }\end{array}$
\end{tabular}

solation are expected to be very similar in all East Antarctic ice core drilling sites, differences in site characteristics (e.g. snow properties, meteorological situation, mean climate) may cause differences in the $\delta \mathrm{O}_{2} / \mathrm{N}_{2}$ signals recorded by the different ice cores. Consequently, we compare the EDC $\delta \mathrm{O}_{2} / \mathrm{N}_{2}$ record with $\delta \mathrm{O}_{2} / \mathrm{N}_{2}$ records from two other ice cores drilled on the East Antarctic Plateau: Vostok and Dome F. In particular, for the three sites, we now benefit from $\delta \mathrm{O}_{2} / \mathrm{N}_{2}, \delta^{18} \mathrm{O}_{\mathrm{atm}}$ and water isotopic composition records across MIS 5. The present-day conditions at these three dry and particularly cold sites depict differences in the distance to open ocean, elevation (within $577 \mathrm{~m}$ ), albedo (within $3 \%$ ), wind speed (a factor of two), accumulation (within $15 \%$ ) and mean annual temperature (within $2.5^{\circ} \mathrm{C}$ ) (Table 1). MIS 5 is characterized by large precession parameter variations, together with large glacial-interglacial changes in Antarctic temperature, and is featured with warmer-than-present reconstructed interglacial temperatures (Sime et al., 2009; Stenni et al., 2010; Masson-Delmotte et al., 2011; Uemura et al., 2012).

Figure 3 displays the $\delta \mathrm{O}_{2} / \mathrm{N}_{2}$ records from Dome $\mathrm{F}$ (transferred on AICC2012 using volcanic matching (Appendix B), Fujita et al., 2015; Kawamura et al., 2007), EDC and Vostok (both on their respective AICC2012 chronologies, Veres et al., 2013; Bazin et al., 2013) from 100 to $150 \mathrm{ka}$. We observe the same orbital scale variations for all three records, i.e. a $\delta \mathrm{O}_{2} / \mathrm{N}_{2}$ maximum at around $126 \mathrm{ka}$ bracketed by 2 minima at 115 and $135 \mathrm{ka}$. Two major differences are still noticeable:

- a lower $\delta \mathrm{O}_{2} / \mathrm{N}_{2}$ mean value and greater amplitude in $\delta \mathrm{O}_{2} / \mathrm{N}_{2}$ variations at Vostok than at Dome F and EDC.

- a site-specific high frequency variability. For instance, between 100 and $115 \mathrm{ka}, \mathrm{EDC}$ and Vostok $\delta \mathrm{O}_{2} / \mathrm{N}_{2}$ records show a double peak (significantly larger than measurements uncertainties). This double peak is not observed in Dome $\mathrm{F} \delta \mathrm{O}_{2} / \mathrm{N}_{2}$ record.

The gas loss corrections applied on the Dome F and Vostok $\delta \mathrm{O}_{2} / \mathrm{N}_{2}$ records may explain part of these discrepancies. The

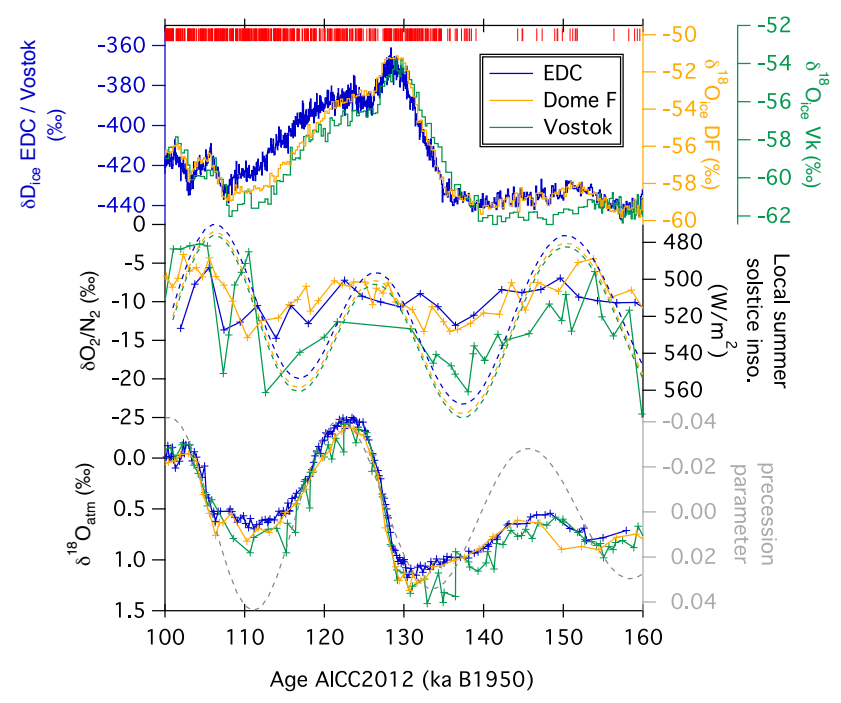

Figure 3. Inter-comparison of Vostok (green), Dome F (yellow) and EDC (blue) data covering MIS 5 presented on AICC2012 (Bazin et al., 2013; Veres et al., 2013), using the volcanic matching between Dome F and EDC published by (Fujita et al., 2015). Top: water isotopic composition (Vostok $\delta^{18} \mathrm{O}_{\text {ice }}$ : Petit et al. (1999), Dome $\mathrm{F}$ $\delta^{18} \mathrm{O}_{\text {ice }}$ : Kawamura et al. (2007), EDC $\delta$ D: Jouzel et al., 2007). Middle: $\delta \mathrm{O}_{2} / \mathrm{N}_{2}$ records and local summer solstice insolation at each site (Suwa and Bender, 2008b; Kawamura et al., 2007, this study). Bottom: $\delta^{18} \mathrm{O}_{\text {atm }}$ and precession parameter shifted by $5 \mathrm{ka}$ (Suwa and Bender, 2008b; Kawamura et al., 2007; Landais et al., 2013, this study).

resolution of the records (2.3 ka for EDC, $1.5 \mathrm{ka}$ for Vostok and $1.2 \mathrm{ka}$ for Dome F between 100 and $150 \mathrm{ka}$ ) limits the comparison of high-frequency variations observed between 100 and $115 \mathrm{ka}$ and around $126 \mathrm{ka}$. Only high-resolution measurements conducted on well-conserved ice could allow us to have an objective discussion of high-frequency signals in Antarctic ice.

Figure 3 presents the water isotopic composition, $\delta \mathrm{O}_{2} / \mathrm{N}_{2}$ and $\delta^{18} \mathrm{O}_{\text {atm }}$ on the AICC2012 timescale, using the volcanic synchronization proposed by Fujita et al. (2015) for Dome F 
data (Appendix B). This timescale transfer removes the original $2 \mathrm{ka}$ shift for Termination II observed between the Dome F (DFO-2006 Kawamura et al., 2007) and AICC2012 chronologies (Bazin et al., 2013). Fujita et al. (2015) have proposed that the large age offset between the DFO-2006 and AICC2012 chronologies originates either from an overestimation of the surface mass balance in the glaciological approach and/or an error in one of the $\delta \mathrm{O}_{2} / \mathrm{N}_{2}$ age constraints by $3 \mathrm{ka}$. At first order, EDC, Vostok and Dome F $\delta \mathrm{O}_{2} / \mathrm{N}_{2}$ records present variations that occur simultaneously with the ones of the local summer solstice insolation target curves (Fig. 3). The identification of the $\delta \mathrm{O}_{2} / \mathrm{N}_{2}$ extrema and mid-slopes within the three records indicates that the $\delta \mathrm{O}_{2} / \mathrm{N}_{2}$ variations can be considered synchronous most of the time, within the calculated uncertainty (3-4ka), for the three sites over this period (Appendix C). However, despite the relatively good agreement between the $\delta \mathrm{O}_{2} / \mathrm{N}_{2}$ records of the different sites, we observe a clear mismatch between the minimum of $\delta \mathrm{O}_{2} / \mathrm{N}_{2}$ and the maximum in insolation over the glacial inception (112-115 ka, Appendices B and C). This mismatch may be attributed to the dating of ice core since the $\delta \mathrm{O}_{2} / \mathrm{N}_{2}$ constraints over MIS 5 were not included in the AICC2012 construction. Aligning $\delta \mathrm{O}_{2} / \mathrm{N}_{2}$ with insolation over the glacial inception would however strongly reduce the lag between precession and $\delta^{18} \mathrm{O}_{\text {atm }}$. While this is a very plausible explanation, we may also question a possible lag between insolation and $\delta \mathrm{O}_{2} / \mathrm{N}_{2}$ variations. Our results from the MIS 5 comparison, as well as the significant $100 \mathrm{ka}$ period observed in the spectral analysis of $\delta \mathrm{O}_{2} / \mathrm{N}_{2}$, suggest a potential influence of local climatic parameters on $\delta \mathrm{O}_{2} / \mathrm{N}_{2}$ variations that complicate the response of snow metamorphism and therefore $\delta \mathrm{O}_{2} / \mathrm{N}_{2}$ to orbital forcing.

First, we investigate how changes in layering or snow microstructure during the firnification processes can affect $\delta \mathrm{O}_{2} / \mathrm{N}_{2}$. Several indices indeed suggest that $\delta \mathrm{O}_{2} / \mathrm{N}_{2}$ is not only influenced by the energy received at the surface of snow but also by firnification processes, which themselves depend on climatic conditions such as accumulation rate, firn temperature or impurity content of the snow (Hutterli et al., 2010). We have thus searched for local climatic influence on $\delta \mathrm{O}_{2} / \mathrm{N}_{2}$ focusing first on accumulation rates. No significant correlation can be identified between EDC accumulation rate produced by AICC2012 and $\delta \mathrm{O}_{2} / \mathrm{N}_{2}$ variations $(R=0.107$ between 340 and $800 \mathrm{ka}$ ). Another approach would be to consider the accumulation rate corresponding to the gas age, following observations by Kobashi et al. (2015) of a significant correlation between the $\delta \mathrm{Ar} / \mathrm{N}_{2}$ on the gas age and the accumulation rate for Greenland ice cores over the Holocene. However, as our $\delta \mathrm{O}_{2} / \mathrm{N}_{2}$ record spans periods with varying insolation conditions, we would first need to correct our $\delta \mathrm{O}_{2} / \mathrm{N}_{2}$ record from insolation variations. Such a correction cannot be performed in a simple way but should be tested in future. Consequently, we only state here that there is most probably a link between accumulation variations and $\delta \mathrm{O}_{2} / \mathrm{N}_{2}$, as previously suspected, but this relation is not linear and needs to be investigated further.

Second, changes in dust concentration have been suggested to potentially influence firn density and hence air trapping (Hörhold et al., 2012; Freitag et al., 2013). Records of dust concentration spanning MIS 5 are available for EDC (Lambert et al., 2008) and Vostok (Petit et al., 1999). There is no significant difference between the dust concentration of Vostok and EDC regarding their amplitude and timing of changes, so they should have the same effect at both sites. The lack of published dust records from Dome F precludes investigations of the differences between Dome $\mathrm{F}$ and Vostok-EDC. Moreover, subsurface processes and reworking of surface snow by the wind are known to have an influence on actual firnification, as a result this should have an impact on the $\delta \mathrm{O}_{2} / \mathrm{N}_{2}$ trapping process (Fujita et al., 2012), even under glacial climatic conditions.

Third, we explore if inter-site differences in surface albedo could explain differences in the energy input for surface snow metamorphism (Picard et al., 2012) and hence differences in $\delta \mathrm{O}_{2} / \mathrm{N}_{2}$ mean levels of the three sites. Surface albedo is currently measured over East Antarctica with MODIS multispectral imager on board TERRA and AQUA satellites. Data collected since 2001 enable to compare the albedo of our three sites of interest (Table 1). For this purpose, White Sky broadband albedo data (surface albedo under perfectly diffuse illumination conditions) were extracted from MCD43A3 products (http://www.umb. edu/spectralmass/terra_aqua_modis/v006). Only values for which local solar noon sun zenith angle is less than $65^{\circ}$ and high-quality flags (QA $=0$ in MCD43A2 products) are considered (Schaaf et al., 2011). They show similar values at Vostok and EDC (0.83), and significantly lower values at Dome F (0.80). This implies that, today, about $15 \%$ more incoming solar radiations are absorbed by Dome F surface snow and can act on its metamorphism. However, surface metamorphism is not simply related to surface albedo. This can be investigated using the grain index time series developed by Picard et al. (2012). The amplitude of diurnal cycles and grain size near the surface indicate more metamorphism at Dome $\mathrm{C}$ than at Dome $\mathrm{F}$. While present-day data provide a hint for possible differences in surface snow metamorphism, further studies are needed to better understand how the surface energy budget controls the surface and subsurface snow metamorphism, and how it can explain the differences in $\delta \mathrm{O}_{2} / \mathrm{N}_{2}$ mean level and phasing between $\delta \mathrm{O}_{2} / \mathrm{N}_{2}$ and insolation forcing at different sites.

Finally, one important assumption for the process linking $\delta \mathrm{O}_{2} / \mathrm{N}_{2}$ and orbital forcing is that the snow metamorphism is maximum at peak temperature (Kawamura et al., 2007) so that summer solstice insolation curve should be taken as orbital target for $\delta \mathrm{O}_{2} / \mathrm{N}_{2}$ variations. At Dome $\mathrm{F}$, the current seasonal cycle of surface snow temperature measurements shows maximum values at the summer solstice (21 December, Kawamura et al., 2007). At Vostok, the maximum of 
surface snow temperature is observed about 10 days later, close to 30 December (continuous measurements since 2010, Lefebvre et al. (2012), J.-R. Petit, personal communication, 2014). At Dome C, 3 years continuous measurements of surface snow temperature between 2006 and 2009 have shown that the maximum of temperature occurs 15-20 days after the summer solstice (Landais et al., 2012, confirmed by the continuous measurements since then). These regional differences highlight the fact that, today, surface snow temperature does not reach its summer maximum in phase with local summer solstice insolation. As a consequence, different insolation target curves for $\delta \mathrm{O}_{2} / \mathrm{N}_{2}$ should be considered for the different sites if the observations performed for present-day conditions are also valid for the past. Using 15 January insolation curve instead of 21 December as orbital target for the EDC $\delta \mathrm{O}_{2} / \mathrm{N}_{2}$ record leads to a $2 \mathrm{ka}$ shift of the chronology toward younger ages over the glacial inception. Finally, by combining the different sources of uncertainty and the scattering and resolution of the $\delta \mathrm{O}_{2} / \mathrm{N}_{2}$ data, we thus recommend using an uncertainty of 3-4 ka for this dating method.

\section{2 $\delta \mathrm{O}_{2} / \mathrm{N}_{2}-\delta^{18} \mathrm{O}_{\mathrm{atm}}$ offset}

A lag of $\delta^{18} \mathrm{O}_{\mathrm{atm}}$ vs precession was observed over the last termination at Vostok, EDC and GISP2 with values of 5.8, 5.9 and $5.3 \mathrm{ka}$ on the FGT1, EDC3 and Meese/Sowers chronologies respectively (Dreyfus et al., 2007; Petit et al., 1999; Parrenin et al., 2004, 2007; Bender et al., 1994; Meese et al., 1994). On the new AICC2012 chronology, the lag of $\delta^{18} \mathrm{O}_{\mathrm{atm}}$ with precession over Termination I is now of $5.6 \mathrm{ka}$ for Vostok and $5.5 \mathrm{ka}$ for EDC.

During Termination II, recently published high-resolution $\delta^{18} \mathrm{O}_{\text {atm }}$ measurements (Landais et al., 2013) together with the AICC2012 chronology (Bazin et al., 2013) also give a $\sim 5 \mathrm{ka}$ phase lag $(5.2 \mathrm{ka})$ between precession and $\delta^{18} \mathrm{O}_{\text {atm }}$. Bazin et al. (2013) have shown an excellent agreement for the timing of Termination II on a purely orbital ice core chronology (AICC2012 using only ice core orbital age markers over Termination II) and an independent speleothem chronology based on U/Th Dating (Cheng et al., 2009). This comparison relies on the assumption that abrupt variations in $\mathrm{CH}_{4}$ and calcite $\delta^{18} \mathrm{O}$ are synchronous. While this assumption was explicitly used to build the EDC3 chronology (Parrenin et al., 2007; Waelbroeck et al., 2008), this is not the case for AICC2012, which provides high confidence in the accuracy of this chronology for Termination II.

The determination of the lag between $\delta^{18} \mathrm{O}_{\mathrm{atm}}$ and precession for earlier terminations is more complicated. Indeed, it requires an absolute chronology that is independent from orbital tuning based on $\delta^{18} \mathrm{O}_{\mathrm{atm}}$. Similarly, determining the phase lag between $\delta \mathrm{O}_{2} / \mathrm{N}_{2}$ and summer solstice insolation is not possible in the absence of an alternative timescale free from $\delta \mathrm{O}_{2} / \mathrm{N}_{2}$ constraints. However, we can still progress on the issue of relative offsets between $\delta^{18} \mathrm{O}_{\mathrm{atm}}, \delta \mathrm{O}_{2} / \mathrm{N}_{2}$ and orbital targets by studying the relationships between $\delta \mathrm{O}_{2} / \mathrm{N}_{2}$ and $\delta^{18} \mathrm{O}_{\mathrm{atm}}$. Indeed, even if the orbital targets of both parameters are close and without significant lags between them (less than 500 years over the last $800 \mathrm{ka}$ ), $\delta^{18} \mathrm{O}_{\mathrm{atm}}$ and $\delta \mathrm{O}_{2} / \mathrm{N}_{2}$ variations are induced by very different mechanisms (remote for $\delta^{18} \mathrm{O}_{\text {atm }}$, local for $\delta \mathrm{O}_{2} / \mathrm{N}_{2}$ ). As a consequence, it is very unlikely that lags or leads of $\delta^{18} \mathrm{O}_{\mathrm{atm}}$ and $\delta \mathrm{O}_{2} / \mathrm{N}_{2}$ relative to their orbital targets would occur simultaneously. These changes should then be visible on the lead and lag between $\delta \mathrm{O}_{2} / \mathrm{N}_{2}$ and $\delta^{18} \mathrm{O}_{\mathrm{atm}}$.

Based on the good agreement of the Vostok and EDC $\delta \mathrm{O}_{2} / \mathrm{N}_{2}$ records over MIS 5, we combine the full Vostok (0-400 ka) and EDC (340-800 ka) $\delta \mathrm{O}_{2} / \mathrm{N}_{2}$ and $\delta^{18} \mathrm{O}_{\mathrm{atm}}$ records (Fig. 4). We re-interpolate the data according to the largest sampling resolution between the $\delta \mathrm{O}_{2} / \mathrm{N}_{2}$ and $\delta^{18} \mathrm{O}_{\text {atm }}$ records of each sites (2.07 ka for EDC and $1.76 \mathrm{ka}$ for Vostok). There is a close resemblance of the interpolated and original data. In order to calculate the relative offset between the two proxy records, we normalize the data (minus the mean, divided by the standard deviation) and filter them using a bandpass filter with 15-100 ka period pass band and wavelet transform. A phase delay between $\delta \mathrm{O}_{2} / \mathrm{N}_{2}$ and $\delta^{18} \mathrm{O}_{\mathrm{atm}}$ is then deduced through the conversion of the phase calculated between the $\delta \mathrm{O}_{2} / \mathrm{N}_{2}$ and $\delta^{18} \mathrm{O}_{\text {atm }}$ filtered records after cross-correlation (hereafter Matlab delay). An independent estimate of the offset has been manually calculated from the identification of the timing of extrema in both records following the same methodology as in Appendix C (hereafter manual delay).

During periods of weak eccentricity (e.g. around $400 \mathrm{ka}$ and before $720 \mathrm{ka}$ ), there is no clear correspondence between the variations of $\delta \mathrm{O}_{2} / \mathrm{N}_{2}$ and $\delta^{18} \mathrm{O}_{\text {atm }}$ compared to the variations of their orbital target curves, as previously noted (Dreyfus et al., 2007; Landais et al., 2012). During these periods, the variations of insolation in the precession band are probably too small to be imprinted in either $\delta \mathrm{O}_{2} / \mathrm{N}_{2}$ or $\delta^{18} \mathrm{O}_{\mathrm{atm}}$ records. Similarly, we prefer not to speculate on the EDC $\delta^{18} \mathrm{O}_{\mathrm{atm}}-\delta \mathrm{O}_{2} / \mathrm{N}_{2}$ offsets between 450 and 550 ka because the $\delta \mathrm{O}_{2} / \mathrm{N}_{2}$ record does not resemble the insolation variations over MIS 13 (Fig. 1). Finally, the most recent 100 ka correspond to a period of low eccentricity and the $\delta \mathrm{O}_{2} / \mathrm{N}_{2}$ signal does not display any clear variability comparable to the insolation curve one (before the air bubbles/clathrates transition). As a consequence, we disregard these periods for our discussion of the phase delay (they are not shown on Fig. 4). Consequently, the orbital tuning through $\delta^{18} \mathrm{O}_{\mathrm{atm}}$ and $\delta \mathrm{O}_{2} / \mathrm{N}_{2}$ is much less reliable over the periods where the two proxies variations do not resemble those in their respective orbital targets. The time intervals covered by the following discussion correspond to 100-350 ka (Vostok data) and 550-720 ka (EDC data).

During the remaining intervals of intermediate to strong eccentricity, the offset between $\delta \mathrm{O}_{2} / \mathrm{N}_{2}$ and $\delta^{18} \mathrm{O}_{\mathrm{atm}}$ varies between -6 and $-1 \mathrm{ka}$ in the Matlab delay and between -8 and +1 ka for the manually calculated one (Fig. 4). The Matlab delay tends to present smoother and less marked varia- 

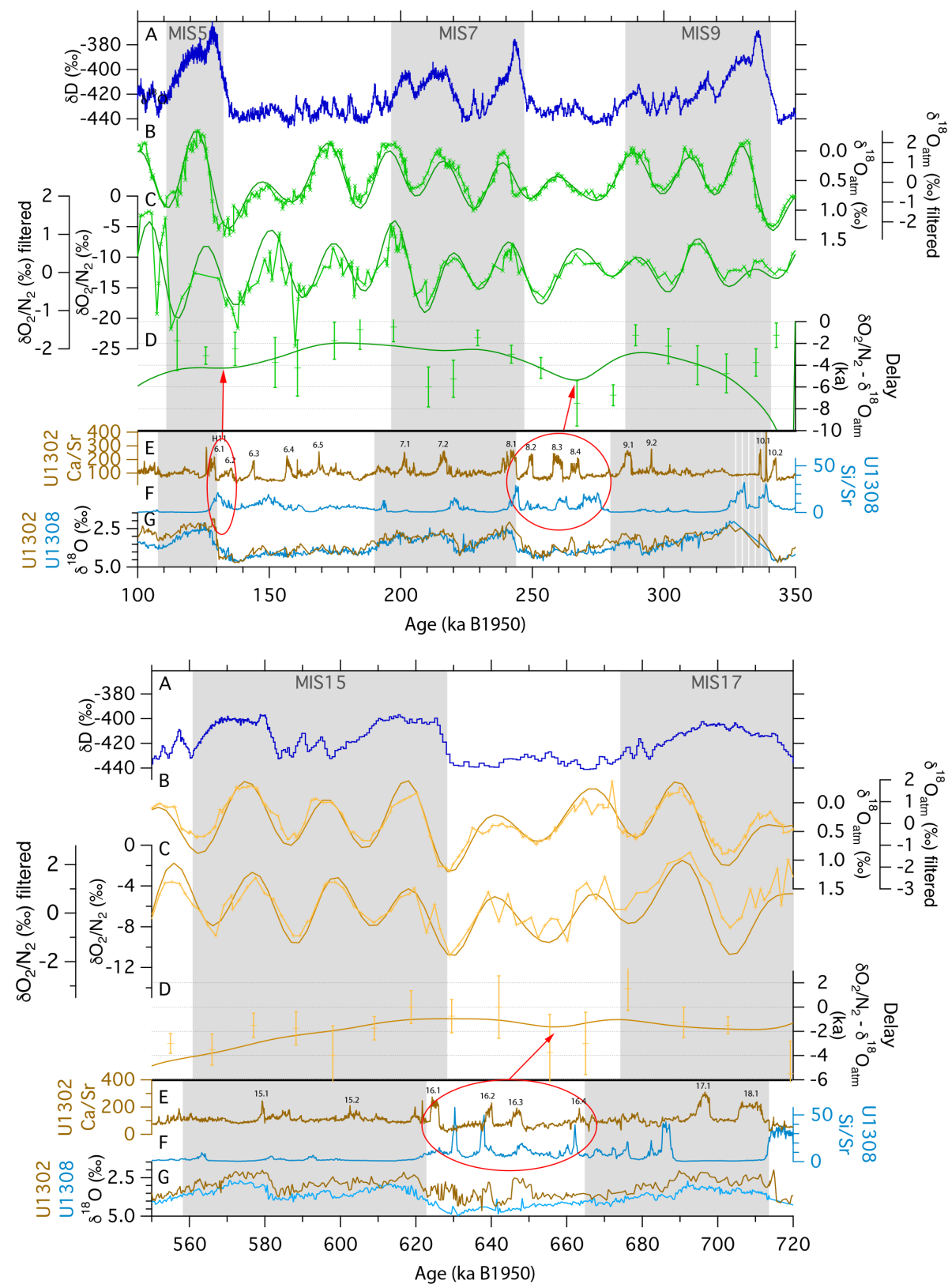

Figure 4. Evolution of the time delay between $\delta \mathrm{O}_{2} / \mathrm{N}_{2}$ and $\delta{ }^{18} \mathrm{O}_{\mathrm{atm}}$ for the periods $100-350 \mathrm{ka}$ (top) and 550-720 ka (bottom). The Vostok data are represented in green and EDC data in yellow. The filtered data are first normalized (minus the mean and divided by the standard deviation) and then filtered using a bandpass filter with 15-100 ka period pass band and wavelet transform in Matlab. Curves A to D correspond to Vostok and EDC ice cores data on the AICC2012 chronology. A: $\delta$ D of EDC, B: $\delta^{18} \mathrm{O}_{\text {atm }}$ on reversed axis (line with markers for raw data and plain line for filtered data), C: $\delta \mathrm{O}_{2} / \mathrm{N}_{2}$ (line with markers for raw data and plain line for filtered data), D: time delay calculated between $\delta \mathrm{O}_{2} / \mathrm{N}_{2}$ and $\delta^{18} \mathrm{O}_{\text {atm }}$ using Matlab (plain curve) and manually (markers with error bars). Curves $\mathrm{E}$ to $\mathrm{G}$ present data from the U1202/03 (brown) and U1308 (light blue) marine cores presented on their respective chronology. E: Ca / Sr ratio, F: Si / Sr ratio, G: $\delta^{18} \mathrm{O}$ planktonic for $\mathrm{U} 1302 / 03$ and $\delta^{18} \mathrm{O}$ benthic for U1308. The grey rectangles mark the MIS intervals in both archives. The numbering in curve E corresponds to the identification of Heinrich-like events as recorded by the Ca / Sr ratio of core U1302/03 and as proposed by Channell et al. (2012). The red circles and arrows show the correspondence between the ice sheets discharge events in the marine records with the maximum delay between $\delta \mathrm{O}_{2} / \mathrm{N}_{2}-\delta^{18} \mathrm{O}_{\mathrm{atm}}$. 
tions than the manual estimate. For Termination II, we obtain a $\delta^{18} \mathrm{O}_{\text {atm }}$ vs $\delta \mathrm{O}_{2} / \mathrm{N}_{2}$ phase delay of $4.5 \mathrm{ka}$, which is in good agreement with the $\delta^{18} \mathrm{O}_{\mathrm{atm}}$ vs precession lag observed on raw data (5.2 ka) and a zero phase between $\delta \mathrm{O}_{2} / \mathrm{N}_{2}$ and summer solstice insolation as displayed on Fig. 3. On Fig. 4, we observe minimal offsets during MIS 6-7, the end of MIS 9, the end of MIS 14-start of MIS 15 and the end of MIS 17. These periods are marked by high eccentricity levels together with intermediate ice-sheet extents (i.e. neither full glacial conditions nor extremely warm interglacial conditions). On the contrary, local maxima of the $\delta \mathrm{O}_{2} / \mathrm{N}_{2}-\delta^{18} \mathrm{O}_{\text {atm }}$ phase delay are observed for Termination II ( $-4.5 \mathrm{ka})$, MIS $8(-5 \mathrm{ka})$ and MIS 16 ( $-2 \mathrm{ka}$ ). Over MIS 15, the offset calculated with Matlab tends to increase while the manually calculated one presents a larger variability.

Part of the variations in the offset value between $\delta \mathrm{O}_{2} / \mathrm{N}_{2}$ and $\delta^{18} \mathrm{O}_{\text {atm }}$ may be due to the uncertainty in the age difference between ice and gas ages since $\delta^{18} \mathrm{O}_{\mathrm{atm}}$ is expressed on a gas timescale while $\delta \mathrm{O}_{2} / \mathrm{N}_{2}$ is on an ice timescale. Such uncertainty is largest during glacial periods, when the $\Delta$ age is larger and the uncertainties on accumulation rate and temperature (i.e. main parameters controlling the firn depth) are larger. However, this uncertainty always stays below $1 \mathrm{ka}$, and therefore cannot explain the observed variations in delay values between $\delta \mathrm{O}_{2} / \mathrm{N}_{2}$ and $\delta^{18} \mathrm{O}_{\mathrm{atm}}$. We argue that the large variations of the lag observed between $\delta \mathrm{O}_{2} / \mathrm{N}_{2}$ and $\delta^{18} \mathrm{O}_{\text {atm }}$ are mainly due to variations in the relationship between $\delta^{18} \mathrm{O}_{\mathrm{atm}}$ and precession as (1) there is nearly no differences in timing of insolation and precession variations, and (2) $\delta \mathrm{O}_{2} / \mathrm{N}_{2}$ can be considered synchronous at first order with local insolation. Indeed, while the exact mechanism linking $\delta \mathrm{O}_{2} / \mathrm{N}_{2}$ to summer solstice insolation is not yet fully understood, there is no doubt that it involves local firn processes with a faster response time. On the opposite, the link between precession and $\delta^{18} \mathrm{O}_{\mathrm{atm}}$ is not direct and involves global modifications of the low-latitude water cycle and biosphere productivity.

Many reasons are invoked to explain the phase lag between precession and $\delta^{18} \mathrm{O}_{\mathrm{atm}}$. As evidenced over Terminations I and II and over the last $240 \mathrm{ka}, \delta^{18} \mathrm{O}_{\text {atm }}$ variations are closely related to the dynamic of the low-latitude hydrological cycle (Wang et al., 2008; Severinghaus et al., 2009; Landais et al., 2007, 2010, 2013; Cheng et al., 2009). Monsoons are influenced by orbital forcing, with a strong imprint of precession (Wang et al., 2008; Braconnot et al., 2008), but also by the millennial-scale variability (Wang et al., 2001; Marzin et al., 2013). The Heinrich event 1 is for instance associated with a weak monsoon interval (e.g. Denton et al., 2010). Severinghaus et al. (2009) have observed a systematic increase of $\delta^{18} \mathrm{O}_{\text {atm }}$ during Heinrich events over the last glacial period, these events being imprinted both in the calcite $\delta^{18} \mathrm{O}$ and ice core $\delta^{18} \mathrm{O}_{\text {atm }}$. Landais et al. (2013) also evidence that the maximum in $\delta^{18} \mathrm{O}_{\mathrm{atm}}$ during Terminations I and II are directly related to the occurrence of large Heinrich events before the abrupt increase in North Atlantic tempera- ture. Again the $\delta^{18} \mathrm{O}_{\mathrm{atm}}$ signal over these two terminations parallels the calcite $\delta^{18} \mathrm{O}$ signals of Chinese speleothems. Following this finding, Reutenauer et al. (2015) used outputs from coupled climate model and atmospheric general circulation model equipped with water isotopes to estimate the change of $\delta^{18} \mathrm{O}_{\mathrm{atm}}$ induced by a freshwater input. These calculations show that the increase of $\delta^{18} \mathrm{O}_{\text {atm }}$ during a Heinrich event is induced by a southward shift of the ITCZ associated with the freshwater input leading to an increase of the $\delta^{18} \mathrm{O}$ of the low-latitude meteoric water in the Northern Hemisphere. This signal is then transmitted to the $\delta^{18} \mathrm{O}$ of $\mathrm{O}_{2}$ through photosynthesis of the important terrestrial biosphere in low latitudes of the Northern Hemisphere during the last glacial period. The occurrence of freshwater input can thus delay the change in $\delta^{18} \mathrm{O}_{\text {atm }}$ induced by the sole insolation. This mechanism would satisfactorily explain a lag in the perceived location of the maximum in the $\delta^{18} \mathrm{O}_{\text {atm }}$ signal compared to the sole influence of precession. Our working hypothesis is thus that we have a superposition of two signals influencing $\delta^{18} \mathrm{O}_{\mathrm{atm}}$ : (1) a direct effect of precession leading to increase of $\delta^{18} \mathrm{O}_{\mathrm{atm}}$ for increasing precession and (2) an influence of Heinrich events, or Greenland and/or European ice sheets discharge events, with the associated weak monsoon intervals leading to an increase of $\delta^{18} \mathrm{O}_{\mathrm{atm}}$.

In order to test our working hypothesis, we confront our $\delta \mathrm{O}_{2} / \mathrm{N}_{2}-\delta^{18} \mathrm{O}_{\mathrm{atm}}$ calculated delay to marine records of Northern ice sheets instabilities from cores U1302/03 and U1308 located within the IRD belt of the North Atlantic (Fig. 4 curves E-G Hodell et al., 2008; Channell et al., 2012; Channell and Hodell, 2013). Sites U1302/03 and U1308 are located on the western and eastern borders of the IRD belt respectively. Heinrich events consist of large iceberg discharges from the Laurentide ice sheet through the Hudson Strait. These events are well recorded by spikes in the $\mathrm{Ca} / \mathrm{Sr}$ ratio, which traces the abundance of carbonate grain in the sediment. On the contrary, IRD events corresponding to discharges of the Greenland and/or European ice sheets (Fennoscandian, British ice sheets mainly) are identified by large amounts of detrital quartz in the sediment, then characterized by peaks in the $\mathrm{Si} / \mathrm{Sr}$ ratio. Consequently, thanks to their respective locations, the $\mathrm{Ca} / \mathrm{Sr}$ record of core U1302/03 is a good proxy for the Hudson Strait iceberg events (Heinrich-like events), and the $\mathrm{Si} / \mathrm{Sr}$ record of core U1308 is a good representative for the Greenland/European ice sheets destabilization events. The marine cores data on Fig. 4 are presented on their original chronologies, constructed by tuning of their $\delta^{18} \mathrm{O}$ to the LR04 benthic stack (Lisiecki and Raymo, 2005). The uncertainty associated with this dating method is estimated to be $4 \mathrm{ka}$ for the last 1 million years. Such a large uncertainty prevents us from any comparison of the absolute timing of ice sheets discharge events with our ice core records. However, the occurrence of IRD events against the $\delta^{18} \mathrm{O}$ record of foraminifer gives us information about their relative timing within the stratigraphy. We thus only discuss the occurrence of Heinrich-like 
events and Greenland and/or European ice sheets discharges in regards to the variation of the $\delta \mathrm{O}_{2} / \mathrm{N}_{2}-\delta^{18} \mathrm{O}_{\mathrm{atm}}$ offset.

We can see that major spikes in $\mathrm{Ca} / \mathrm{Sr}$ and $\mathrm{Si} / \mathrm{Sr}$ recorded in the marine cores occur at roughly the same periods as the maxima in the $\delta \mathrm{O}_{2} / \mathrm{N}_{2}-\delta^{18} \mathrm{O}_{\text {atm }}$ phase delay. The correspondence is especially well marked in the manually calculated offsets (red circles and arrows on Fig. 4). The $\delta \mathrm{O}_{2} / \mathrm{N}_{2}-\delta^{18} \mathrm{O}_{\text {atm }}$ phase delays are small over MIS 15. In the marine records of iceberg discharges, only small but regular peaks in the $\mathrm{Ca} / \mathrm{Sr}$ record are observed during this period. For Channell et al. (2012), these peaks do not reflect the occurrence of Heinrich-like events but most probably correspond to debris flows or glacial-lake drainage events caused by changes in hydrological budget or changes in base level.

Interpreting the chosen marine data as proxies of Laurentide and Greenland and/or European ice sheets discharges, probably associated with weak monsoon intervals as observed for several Heinrich events, we suggest that for Termination II, MIS 8 and MIS 16, the $\delta^{18} \mathrm{O}_{\mathrm{atm}}$ is strongly influenced by the millennial variability in addition to the precession forcing on the low-latitude hydrological cycle.The addition of the millennial influence leads to significant observable shifts between precession and $\delta^{18} \mathrm{O}_{\mathrm{atm}}$, hence $\delta \mathrm{O}_{2} / \mathrm{N}_{2}$ and $\delta^{18} \mathrm{O}_{\mathrm{atm}}$. By contrast, when we detect the smallest offsets between $\delta \mathrm{O}_{2} / \mathrm{N}_{2}$ and $\delta^{18} \mathrm{O}_{\text {atm }}$ (Fig. 4), no discharge events are observed within our marine core records. In this last case and following our working hypothesis, $\delta^{18} \mathrm{O}_{\mathrm{atm}}$ would be only influenced by orbital variability with, hence, a close coupling between precession and $\delta^{18} \mathrm{O}_{\mathrm{atm}}$.

In summary, our data sets suggest that the offset between $\delta^{18} \mathrm{O}_{\mathrm{atm}}$ and precession can vary between $1 \mathrm{ka}$ to more than $6 \mathrm{ka}$, with minimum values in the absence of ice sheets discharge events (Heinrich-like and/or Greenland/European ice sheets discharges). This varying lag results from the superposition of two signals, i.e. orbital and millennial variations affecting changes in the low-latitude water cycle (hence $\delta^{18} \mathrm{O}$ of meteoric water) and the biosphere productivity. It follows that the delay identified between $\delta^{18} \mathrm{O}_{\mathrm{atm}}$ and precession over Termination I and II may not apply for earlier transitions without ice sheets discharge events. Consequently, the phase lag between $\delta^{18} \mathrm{O}_{\mathrm{atm}}$ and precession observed during Termination I may provide an upper estimate for the associated uncertainty range for the use of $\delta^{18} \mathrm{O}_{\mathrm{atm}}$ as an orbital dating tool.

\section{Conclusions and perspectives}

We have presented new measurements of $\delta \mathrm{O}_{2} / \mathrm{N}_{2}$ and $\delta^{18} \mathrm{O}_{\text {atm }}$ performed on well-conserved ice from EDC over MIS 5 and between 340 and $800 \mathrm{ka}$. As a result, we now have a new reference $\delta \mathrm{O}_{2} / \mathrm{N}_{2}$ curve between 340 and $800 \mathrm{ka}$ with a mean resolution of $2.08 \mathrm{ka}$, confirming earlier observations about a decreasing trend over the last $800 \mathrm{ka}$ and timing of orbital scale variations. The spectral analysis of the new $\delta \mathrm{O}_{2} / \mathrm{N}_{2}$ curve between 340 and $800 \mathrm{ka}$ showed for the first time a significant peak in the periodicity band characterizing eccentricity and glacial-interglacial variations, hence suggesting that processes other than local summer insolation do impact $\delta \mathrm{O}_{2} / \mathrm{N}_{2}$ on glacial-interglacial scales. This motivates further studies to unveil the processes at play for long-term trends and at glacial-interglacial and/or eccentricity timescales.

Thanks to our comprehensive data set, we have been able for the first time to compare the sequence of events between water stable isotopes, $\delta \mathrm{O}_{2} / \mathrm{N}_{2}$ and $\delta^{18} \mathrm{O}_{\text {atm }}$ for three Antarctic ice cores (EDC, Vostok and Dome F), over MIS 5. The combination of $\delta \mathrm{O}_{2} / \mathrm{N}_{2}$ records from the three sites has permitted us to estimate the uncertainty of the $\delta \mathrm{O}_{2} / \mathrm{N}_{2}$ orbital tuning method to be in the order of 3-4 ka. However, differences in the mean level of $\delta \mathrm{O}_{2} / \mathrm{N}_{2}$ and their highfrequency variability have been noticed. This study demonstrates the strength of a multi-proxy, multi-ice cores chronology approach for proper assessment of uncertainties of individual age markers. The mechanisms responsible for local $\delta \mathrm{O}_{2} / \mathrm{N}_{2}$ variations still remain to be understood. This is particularly important over periods of low eccentricity when the insolation variations are not well imprinted in the $\delta \mathrm{O}_{2} / \mathrm{N}_{2}$ records (350-450 and 700-800 ka). The $\delta \mathrm{O}_{2} / \mathrm{N}_{2}$ orbital tuning method should be used in combination with other dating methods over these periods.

We have calculated the phase delay between $\delta \mathrm{O}_{2} / \mathrm{N}_{2}$ and $\delta^{18} \mathrm{O}_{\text {atm }}$ over the last $800 \mathrm{ka}$ by coupling Vostok and EDC data. This lag has varied from 1 to more than $6 \mathrm{ka}$ with minimum values occurring during MIS 6-7, the end of MIS 9, the end of MIS 14-start of MIS 15 and the end of MIS 17, corresponding to periods of intermediate ice sheet extent with no occurrence of strong ice sheets discharge events (Heinrichlike events and/or Greenland/European ice sheets discharge events). Based on results observed over MIS 5, we made the assumption that $\delta \mathrm{O}_{2} / \mathrm{N}_{2}$ is more or less synchronous with summer solstice insolation and that the $\delta \mathrm{O}_{2} / \mathrm{N}_{2}-\delta^{18} \mathrm{O}_{\text {atm }}$ varying lag is mainly induced by variations in the relationship between $\delta^{18} \mathrm{O}_{\mathrm{atm}}$ and precession. It has been shown over Terminations I and II that the $\delta^{18} \mathrm{O}_{\mathrm{atm}}$ response to precession peak can be delayed by Heinrich events, associated with weak monsoon intervals. We thus propose that the variations of the apparent lag between $\delta^{18} \mathrm{O}_{\mathrm{atm}}$ and $\delta \mathrm{O}_{2} / \mathrm{N}_{2}$ is due to the superposition of two influences on the $\delta^{18} \mathrm{O}_{\mathrm{atm}}$ signal: orbital (precession) forcing and millennial scale forcing induced by ice sheets discharge events associated with weak monsoon intervals on the low-latitude hydrological cycle. This $\delta^{18} \mathrm{O}$ signal of meteoric water was transmitted to $\delta^{18} \mathrm{O}_{\mathrm{atm}}$ by photosynthesis and/or respiration cycles.

In order to refine this analysis, new measurements on wellconserved ice of $\delta \mathrm{O}_{2} / \mathrm{N}_{2}$ and $\delta^{18} \mathrm{O}_{\mathrm{atm}}$ are needed between 160 and $340 \mathrm{ka}$ for the EDC ice core, and over the last $400 \mathrm{ka}$ for Vostok and Dome F ice cores. Integrating Dome $\mathrm{F}$ on the AICC2012 age scale will be crucial to improve the Antarctic chronology. This methodology will then permit us to investigate properly the causes of inter-site differences during 
MIS 5, and assess if similar features arise during other time periods. New measurements on well-conserved ice together with constraints on past changes in dust concentration and accumulation rates should allow us to assess whether there is any robust link between variables that can potentially affect metamorphism such as dust content and accumulation rate. Moreover, further studies are needed on processes affecting surface snow in order to better understand its metamorphism. Finally, it is crucial to better understand how the low-latitude water cycle and biosphere productivity influence the $\delta^{18} \mathrm{O}_{\mathrm{atm}}$ and its lagged response to precession in order to estimate correctly the uncertainty associated with the $\delta^{18} \mathrm{O}_{\text {atm }}$ orbital tuning methods. To do so, it is necessary to improve uncertainties associated with ice and marine cores chronology. The development of multi-archive dating tools should permit us to synchronize records from different archives and thus discuss in more detail how the ice sheets discharge events influence the $\delta^{18} \mathrm{O}_{\mathrm{atm}}$ lag with precession. This will especially permit to directly link $\delta^{18} \mathrm{O}_{\mathrm{atm}}$ variations with absolutely dated speleothem records. 
Appendix A: $\operatorname{EDC} \delta \mathrm{O}_{2} / \mathrm{N}_{2}$ records

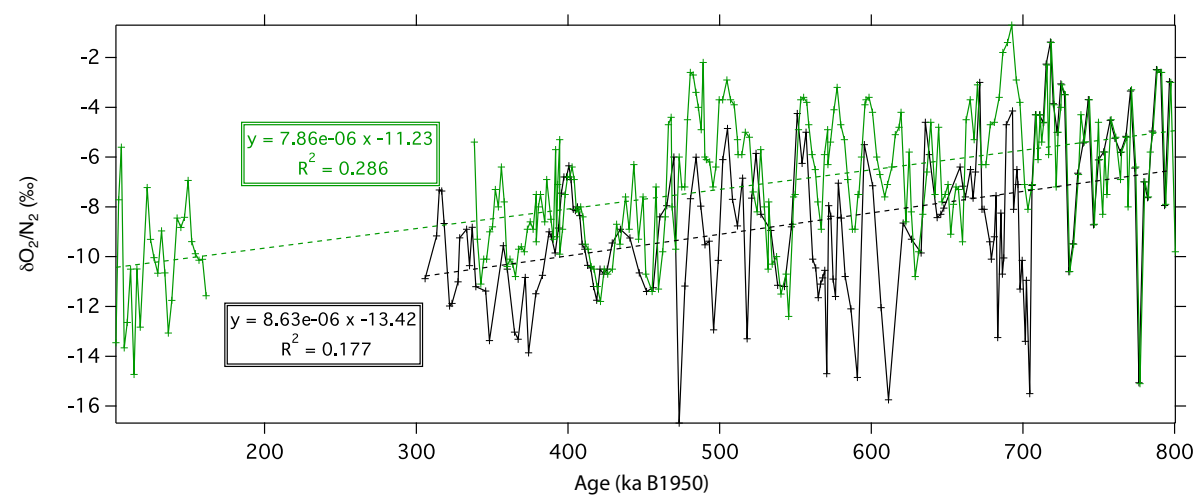

Figure A1. Comparison of the composite $\delta \mathrm{O}_{2} / \mathrm{N}_{2}$ record of Landais et al. (2012) (black) and the new $\delta \mathrm{O}_{2} / \mathrm{N}_{2}$ record measured on wellconserved ice (green). Both are presented on the AICC2012 chronology.

We have compared the $\delta \mathrm{O}_{2} / \mathrm{N}_{2}$ composite curve of Landais et al. (2012), corrected for gas loss, with our new record measured only on well-conserved ice (Fig. A1). We observe nearly the same timing of variations. We conclude that the increased resolution and accuracy of our new data set do not affect the position of mid-slope variations and therefore orbital tuning. The uncertainty associated with the mid-slope identification is always smaller than the uncertainty associated with $\delta \mathrm{O}_{2} / \mathrm{N}_{2}$ orbital tuning. Note that we have identified an error in the earlier composite curve due to the use of gas age instead of ice age for the time period 400 to $450 \mathrm{ka}$. This error has been corrected and explains the difference between our new record and the one of Landais et al. (2012). Compared to the Landais et al. (2012) composite curve, the new record presents a smaller amplitude of variations, possibly because of gas loss corrections. Our new data record a long-term decrease of $\delta \mathrm{O}_{2} / \mathrm{N}_{2}$ over time of $0.78 \pm 0.08 \% \circ 100 \mathrm{ka}^{-1}$, which is very close to the longterm decrease of $0.86 \pm 0.14 \% \circ 100 \mathrm{ka}^{-1}$, deduced from the Landais et al. (2012) composite curve. 
Appendix B: Volcanic matching between EDC and Dome F

Thanks to the volcanic synchronization of EDC and Dome F of Fujita et al. (2015), we were then able to transfer (1) Dome F data $\left(\delta^{18} \mathrm{O}_{\text {ice }}, \delta \mathrm{O}_{2} / \mathrm{N}_{2}\right.$ and $\left.\delta^{18} \mathrm{O}_{\text {atm }}\right)$ on DFO2006 chronology to AICC2012 and (2) EDC data from AICC2012 to DFO-2006 chronology (Fig. B1). As can be seen on Fig. B1, there are numerous volcanic markers (red markers on top) between these two cores over the whole MIS 5 period. This volcanic synchronization is robust and independent of any climatic assumption. As noted by Fujita et al. (2015), this volcanic synchronization does not resolve the difference of ice isotopic composition over the glacial inception at these two sites. Potential causes for this large age difference between the DFO-2006 and AICC2012 chronologies are the following: an overestimation of the surface mass balance in the glaciological approach and/or an error in one of Dome $\mathrm{F} \delta \mathrm{O}_{2} / \mathrm{N}_{2}$ age constraint by $3 \mathrm{ka}$. Moreover, the shaded areas on Fig. B1 highlight the different occurrence of the $\delta \mathrm{O}_{2} / \mathrm{N}_{2}$ minima relative to the ice isotopic composition records. For EDC data, the $\delta \mathrm{O}_{2} / \mathrm{N}_{2}$ minimum is happening during the second half of the glacial inception, while at Dome $\mathrm{F}$ the $\delta \mathrm{O}_{2} / \mathrm{N}_{2}$ minimum is observed at the end of the glacial inception in the ice isotopic composition record.
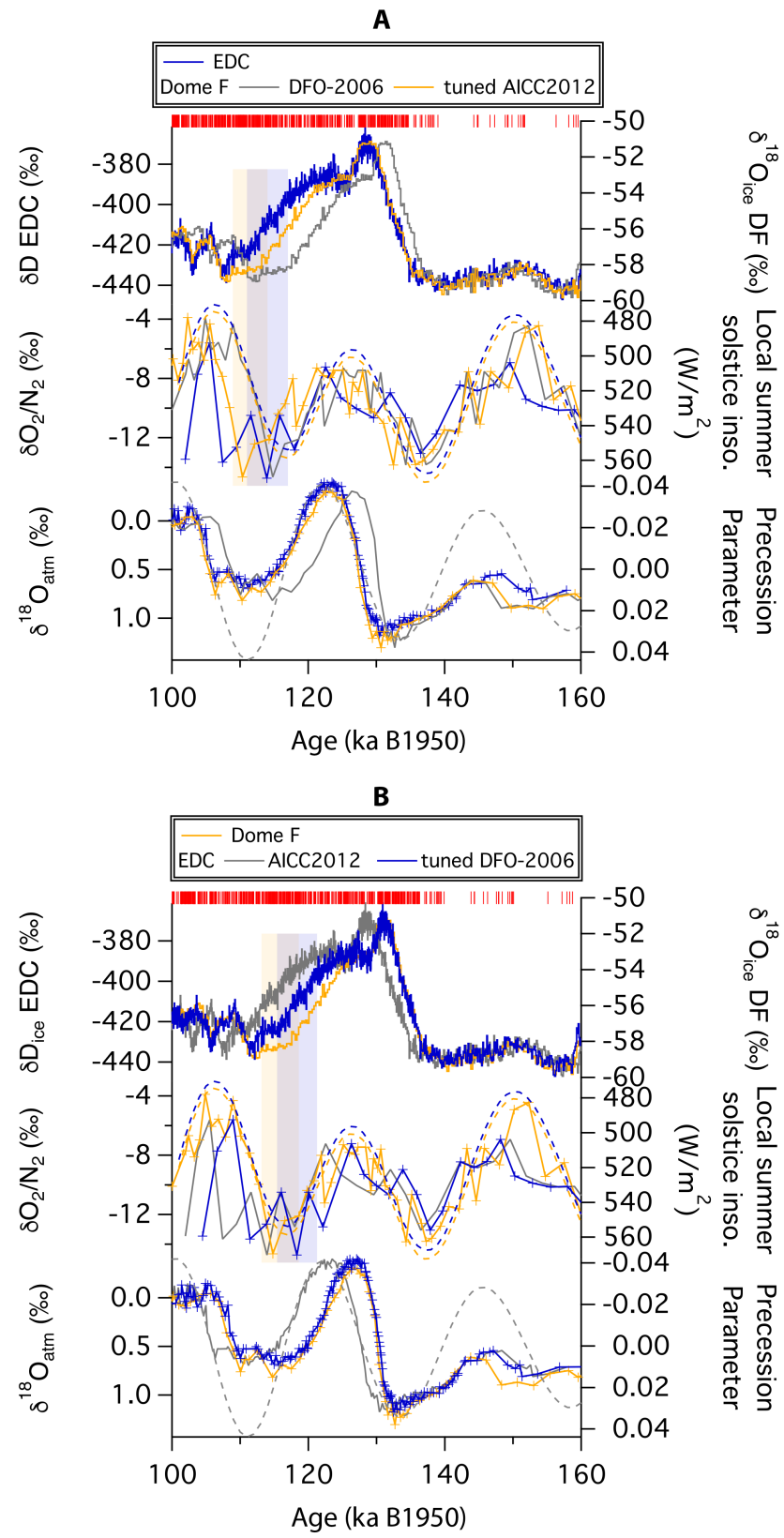

Figure B1. EDC and Dome F synchronization using the volcanic matching of Fujita et al. (2015). (a): transfer of Dome F records on AICC2012, (b): transfer of EDC records on DFO-2006 using the volcanic tie points of Fujita et al. (2015). The coloured curves represent EDC and Dome F records tuned together on either chronologies. The grey curves correspond to the data on their original chronology, before tuning. Top: $\delta \mathrm{D}$ record of EDC and $\delta^{18} \mathrm{O}_{\text {ice }}$ record of Dome F. Middle: $\delta \mathrm{O}_{2} / \mathrm{N}_{2}$ records and local summer solstice insolation. Bottom: $\delta^{18} \mathrm{O}_{\mathrm{atm}}$ records and precession parameter shifted by $5 \mathrm{ka}$. The yellow and blue shaded area highlight the relative position of $\delta \mathrm{O}_{2} / \mathrm{N}_{2}$ minima (uncertainty range) within the water isotopic composition records. The volcanic tie points are indicated by the red markers on top of the figures. 
Appendix C: Estimation of the uncertainty associated with orbital tuning

Table C1. Mean age and uncertainty calculated for minima, mid-slopes and maxima in the $\delta \mathrm{O}_{2} / \mathrm{N}_{2}$ records of EDC, Vostok and Dome F over MIS 5.

\begin{tabular}{|c|c|c|c|c|c|c|c|c|c|c|}
\hline & & $\max 1$ & mid & $\min 1$ & mid & $\max 2$ & mid & $\min 2$ & $\operatorname{mid}$ & $\max 3$ \\
\hline \multirow{2}{*}{ EDC } & mean $(\mathrm{ka})$ & 104.7 & 107.7 & 114.0 & 119.0 & 123.8 & 131.8 & 136.0 & 141.3 & 148.3 \\
\hline & error $(\mathrm{ka})$ & 3.0 & 3.0 & 3.0 & 2.9 & 3.0 & 3.2 & 3.4 & 3.7 & 4.1 \\
\hline \multirow{2}{*}{ Vostok } & mean $(\mathrm{ka})$ & 104.8 & 110.8 & 115.0 & 119.0 & 126.3 & 133.3 & 137.0 & 144.5 & 152.5 \\
\hline & error $(\mathrm{ka})$ & 2.7 & 2.5 & 2.7 & 2.7 & 2.8 & 2.8 & 3.2 & 3.4 & 3.6 \\
\hline \multirow{2}{*}{ Dome F (DFO-2006) } & mean (ka) & 106.5 & 112.0 & 115.8 & 120.3 & 126.5 & 132.0 & 138.0 & 144.5 & 151.0 \\
\hline & error (ka) & 2.8 & 2.7 & 2.7 & 2.7 & 3.0 & 2.9 & 2.9 & 4.4 & 4.4 \\
\hline \multirow{2}{*}{ Dome F (tuned AICC2012) } & mean $(\mathrm{ka})$ & 103.3 & 108.1 & 111.5 & 117.0 & 124.0 & 129.4 & 136.3 & 145.5 & 152.8 \\
\hline & error (ka) & 2.4 & 2.5 & 2.5 & 2.5 & 2.4 & 2.6 & 3.0 & 3.3 & 3.7 \\
\hline
\end{tabular}

In this paper we propose an uncertainty estimation for the $\delta \mathrm{O}_{2} / \mathrm{N}_{2}$ orbital tuning method based on the comparison of $\delta \mathrm{O}_{2} / \mathrm{N}_{2}$ records of EDC, Vostok and Dome F (both on DFO2006 and tuned on AICC2012) over MIS 5. In order to estimate the uncertainty in the identification of minima, maxima or mid-slopes in the $\delta \mathrm{O}_{2} / \mathrm{N}_{2}$ records we have treated the three $\delta \mathrm{O}_{2} / \mathrm{N}_{2}$ records as follow:

1. the raw data,

2. a 3-point running average of the $\delta \mathrm{O}_{2} / \mathrm{N}_{2}$,

3. reinterpolation of the data with a time step corresponding to the mean resolution of each $\delta \mathrm{O}_{2} / \mathrm{N}_{2}$ record (2.37 ka for EDC, $1.87 \mathrm{ka}$ for Vostok and $1.69 \mathrm{ka}$ for Dome F),

4. filtering of the reinterpolated data (piecewise linear shape with a slope bandwidth of $10^{-9} \mathrm{a}^{-1}$ and a bandpass filter with 15-100 ka period pass band using Analyseries, Paillard et al., 1996).

We have identified the minima, mid-slopes and maxima for the $4 \delta \mathrm{O}_{2} / \mathrm{N}_{2}$ treated records of the different sites. We were then able to calculate the mean age and standard deviation for each of these identifications (Table C1). The final uncertainty associated with the identification of the extrema and mid-slopes of the $\delta \mathrm{O}_{2} / \mathrm{N}_{2}$ records has been obtained after considering also the resolution of the records and the uncertainty of their respective chronologies (Table C1). The results are illustrated on Fig. C1 where the pink lines and shaded zones correspond to the mean age and uncertainty of minima and maxima of $\delta \mathrm{O}_{2} / \mathrm{N}_{2}$ for EDC (a), Vostok (b) and Dome $\mathrm{F}$ on DFO-2006 (c) and Dome F on AICC2012 (d). The grey bars indicate the position of minima and maxima as identified in the local summer solstice insolation for comparison. 


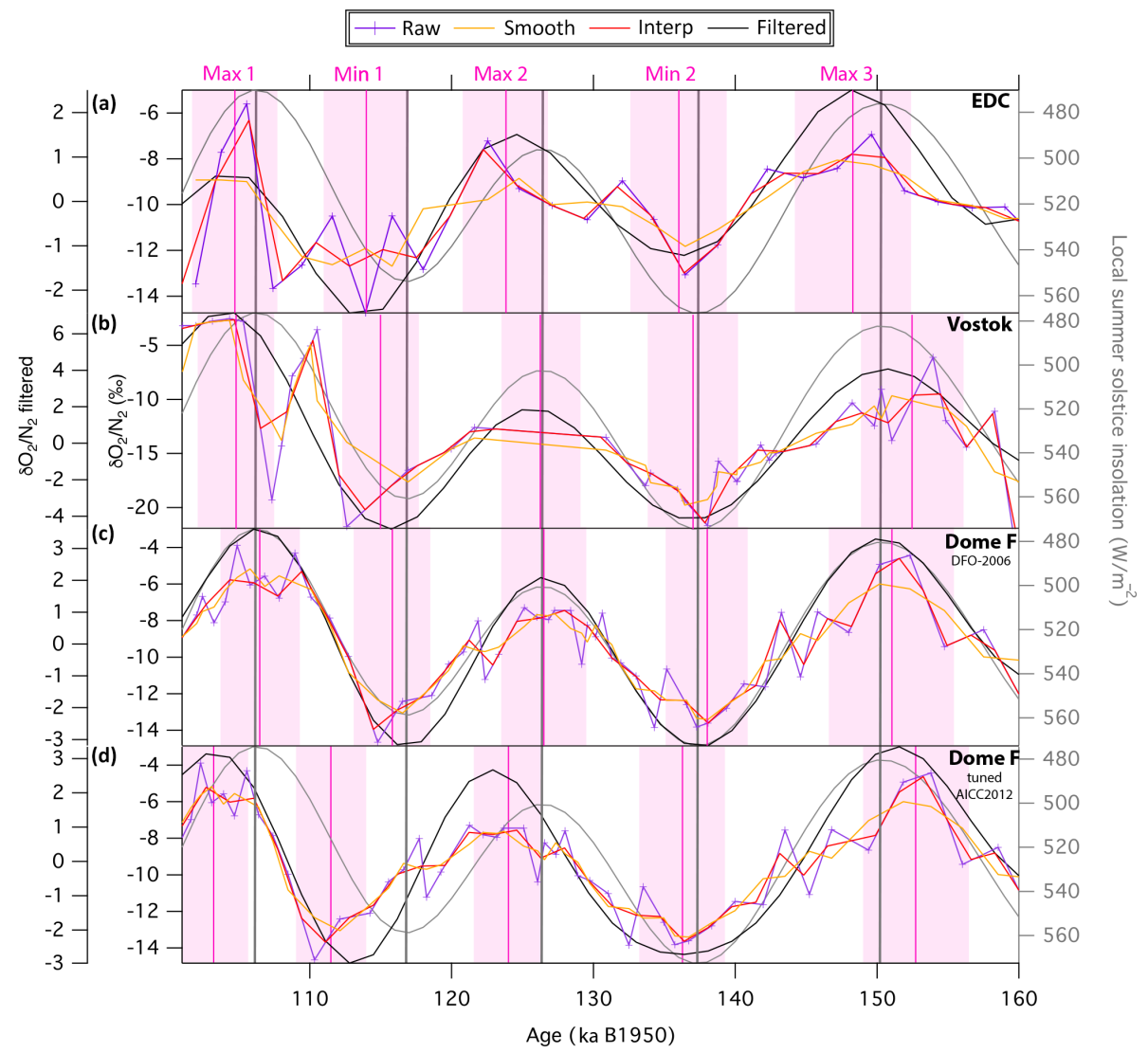

Figure C1. Determination of the uncertainty associated with $\delta \mathrm{O}_{2} / \mathrm{N}_{2}$ orbital tuning using different treatment of data for EDC (a), Vostok (b) Dome F on DFO-2006 (c) and Dome F tuned on AICC2012 (d) over MIS 5. The raw $\delta \mathrm{O}_{2} / \mathrm{N}_{2}$ records are presented in purple, the smoothed ones (3-points running average) are in orange, the reinterpolated curves are presented in red and the filtered records are in black. The local summer solstice insolation are represented in grey for each site. The pink vertical bars represent the mean age of minima and maxima identified, with their calculated uncertainty illustrated by the pink shaded zones. The identification of extrema indicated on top of the figure corresponds to the same ID as in Table $\mathrm{C} 1$. The grey vertical bars show the timing of minima and maxima in the insolation curves. 
Acknowledgements. We address our first acknowledgements to the two anonymous reviewers and the editor for their implication in the review process. We thank Jean-Robert Petit and Laurent Arnaud for the help with the surface temperature data of Vostok and EDC. We thank James Channell for the marine core data. The present research project no. 902 has been performed at Concordia Station and was supported by the French Polar Institute (IPEV). This project was funded by the "Fondation de France Ars Cuttoli" and the "ANR Citronnier". The research leading to these results has received funding from the European Union's Seventh Framework programme (FP7/2007-2013) under grant agreement no. 243908, "Past4Future. Climate change - Learning from the past climate". This is LSCE contribution no. 5701.

Edited by: A. Paul

\section{References}

Battle, M., Bender, M., Sowers, T., Tans, P. P., Butler, J. H., Elkins, J. W., Ellis, J. T., Conway, T., Zhang, N., Lang, P., and Clarket, A. D.: Atmospheric gas concentrations over the past century measured in air from firn at the South Pole, Nature, 383, 231235, doi:10.1038/383231a0, 1996.

Bazin, L., Landais, A., Lemieux-Dudon, B., Toyé Mahamadou Kele, H., Veres, D., Parrenin, F., Martinerie, P., Ritz, C., Capron, E., Lipenkov, V., Loutre, M.-F., Raynaud, D., Vinther, B., Svensson, A., Rasmussen, S. O., Severi, M., Blunier, T., Leuenberger, M., Fischer, H., Masson-Delmotte, V., Chappellaz, J., and Wolff, E.: An optimized multi-proxy, multi-site Antarctic ice and gas orbital chronology (AICC2012): 120-800 ka, Clim. Past, 9, 17151731, doi:10.5194/cp-9-1715-2013, 2013.

Bender, M., Sowers, T., and Labeyrie, L.: The Dole effect and its variations during the last 130,000 years as measured in the Vostok ice core, Global Biogeochem. Cy., 8, 363-376, doi:10.1029/94GB00724, 1994.

Bender, M., Sowers, T., and Lipenkov, V.: On the concentrations of $\mathrm{O}_{2}, \mathrm{~N}_{2}$, and $\mathrm{Ar}$ in trapped gases from ice cores, J. Geophys. Res.-Atmos., 100, 18651-18660, doi:10.1029/94JD02212, 1995.

Bender, M. L.: Orbital tuning chronology for the Vostok climate record supported by trapped gas composition, Earth Planet. Sc. Lett., 204, 275-289, doi:10.1016/S0012-821X(02)00980-9, 2002.

Braconnot, P., Marzin, C., Grégoire, L., Mosquet, E., and Marti, O.: Monsoon response to changes in Earth's orbital parameters: comparisons between simulations of the Eemian and of the Holocene, Clim. Past, 4, 281-294, doi:10.5194/cp-4-281-2008, 2008.

Buiron, D., Chappellaz, J., Stenni, B., Frezzotti, M., Baumgartner, M., Capron, E., Landais, A., Lemieux-Dudon, B., MassonDelmotte, V., Montagnat, M., Parrenin, F., and Schilt, A.: TALDICE-1 age scale of the Talos Dome deep ice core, East Antarctica, Clim. Past, 7, 1-16, doi:10.5194/cp-7-1-2011, 2011.

Caley, T., Malaizé, B., Revel, M., Ducassou, E., Wainer, K., Ibrahim, M., Shoeaib, D., Migeon, S., and Marieu, V.: Orbital timing of the Indian, East Asian and African boreal monsoons and the concept of a 11global monsoon", Quaternary Sci. Rev., 30, 3705-3715, doi:10.1016/j.quascirev.2011.09.015, 2011.

Channell, J., Hodell, D., Romero, O., Hillaire-Marcel, C., de Vernal, A., Stoner, J., Mazaud, A., and Röhl, U.: A 750-kyr detrital-layer stratigraphy for the North Atlantic (IODP Sites U1302-U1303, Orphan Knoll, Labrador Sea), Earth Planet. Sc. Lett., 317-318, 218-230, doi:10.1016/j.epsl.2011.11.029, 2012.

Channell, J. E. T. and Hodell, D. A.: Magnetic signatures of Heinrich-like detrital layers in the Quaternary of the North Atlantic, Earth Planet. Sc. Lett., 369, 260-270, doi:10.1016/j.eps1.2013.03.034, 2013.

Cheng, H., Edwards, R. L., Broecker, W. S., Denton, G. H., Kong, X., Wang, Y., Zhang, R., and Wang, X.: Ice Age Terminations, Science, 326, 248-252, doi:10.1126/science.1177840, 2009.

Denton, G. H., Anderson, R. F., Toggweiler, J. R., Edwards, R. L., Schaefer, J. M., and Putnam, A. E.: The Last Glacial Termination, Science, 328, 1652-1656, doi:10.1126/science.1184119, 2010.

Dreyfus, G. B., Parrenin, F., Lemieux-Dudon, B., Durand, G., Masson-Delmotte, V., Jouzel, J., Barnola, J.-M., Panno, L., Spahni, R., Tisserand, A., Siegenthaler, U., and Leuenberger, M.: Anomalous flow below $2700 \mathrm{~m}$ in the EPICA Dome $\mathrm{C}$ ice core detected using $\delta^{18} \mathrm{O}$ of atmospheric oxygen measurements, Clim. Past, 3, 341-353, doi:10.5194/cp-3-341-2007, 2007.

Dreyfus, G. B., Raisbeck, G. M., Parrenin, F., Jouzel, J., Guyodo, Y., Nomade, S., and Mazaud, A.: An ice core perspective on the age of the Matuyama-Brunhes boundary, Earth Planet. Sc. Lett., 274, 151-156, doi:10.1016/j.epsl.2008.07.008, 2008.

Freitag, J., Kipfstuhl, S., Laepple, T., and Wilhelms, F.: Impuritycontrolled densification: a new model for stratified polar firn, J. Glaciol., 59, 1163-1169, doi:10.3189/2013JoG13J042, 2013.

Fujita, S., Okuyama, J., Hori, A., and Hondoh, T.: A mechanism for local insolation modulation of gas transport conditions during bubble close off, J. Geophys. Res., 114, F03023, 2009.

Fujita, S., Enomoto, H., Fukui, K., Iizuka, Y., Motoyama, H., Nakazawa, F., Sugiyama, S., and Surdyk, S.: Formation and metamorphism of stratified firn at sites located under spatial variations of accumulation rate and wind speed on the East Antarctic ice divide near Dome Fuji, The Cryosphere Discuss., 6, 12051267, doi:10.5194/tcd-6-1205-2012, 2012.

Fujita, S., Parrenin, F., Severi, M., Motoyama, H., and Wolff, E. W.: Volcanic synchronization of Dome Fuji and Dome C Antarctic deep ice cores over the past $216 \mathrm{kyr}$, Clim. Past, 11, 1395-1416, doi:10.5194/cp-11-1395-2015, 2015.

Hodell, D. A., Channell, J. E. T., Curtis, J. H., Romero, O. E., and RöHl, U.: Onset of "Hudson Strait" Heinrich events in the eastern North Atlantic at the end of the middle Pleistocene transition $(\sim 640 \mathrm{ka})$ ?, Paleoceanography, 23, 4218, doi:10.1029/2008PA001591, 2008.

Hörhold, M., Laepple, T., Freitag, J., Bigler, M., Fischer, H., and Kipfstuhl, S.: On the impact of impurities on the densification of polar firn , Earth Planet. Sc. Lett., 325-326, 93-99, doi:10.1016/j.eps1.2011.12.022, 2012.

Huber, C., Beyerle, U., Leuenberger, M., Schwander, J., Kipfer, R., Spahni, R., Severinghaus, J. P., and Weiler, K.: Evidence for molecular size dependent gas fractionation in firn air derived from noble gases, oxygen, and nitrogen measurements, Earth Planet. Sc. Lett., 243, 61-73, doi:10.1016/j.epsl.2005.12.036, 2006.

Hutterli, M. A., Schneebeli, M., Freitag, J., Kipfstuhl, J., and Rothlisberger, R.: Impact of local insolation on snow metamorphism and ice core records, Physics of ice core records II, edited by: 
Hondoh, T., Hokkaido University Press, Sapporo, Japan, 223$232,2010$.

Ikeda-Fukazawa, T., Fukumizu, K., Kawamura, K., Aoki, S., Nakazawa, T., and Hondoh, T.: Effects of molecular diffusion on trapped gas composition in polar ice cores, Earth Planet. Sc. Lett., 229, 183-192, doi:10.1016/j.eps1.2004.11.011, 2005.

Imbrie, J. and Imbrie, J. Z.: Modeling the Climatic Response to Orbital Variations, Science, 207, 943-953, doi:10.1126/science.207.4434.943, 1980.

Jouzel, J., Waelbroeck, C., Malaize, B., Bender, M., Petit, J., Stievenard, M., Barkov, N., Barnola, J., King, T., Kotlyakov, V., Lipenkov, V., Lorius, C., Raynaud, D., Ritz, C., and Sowers, T.: Climatic interpretation of the recently extended Vostok ice records, Clim. Dynam., 12, 513-521, doi:10.1007/BF00207935, 1996.

Jouzel, J., Hoffmann, G., Parrenin, F., and Waelbroeck, C.: Atmospheric oxygen 18 and sea-level changes, Quaternary Sci. Rev., 21, 307-314, doi:10.1016/S0277-3791(01)00106-8, 2002.

Jouzel, J., Masson-Delmotte, V., Cattani, O., Dreyfus, G., Falourd, S., Hoffmann, G., Minster, B., Nouet, J., Barnola, J. M., Chappellaz, J., Fischer, H., Gallet, J. C., Johnsen, S., Leuenberger, M., Loulergue, L., Luethi, D., Oerter, H., Parrenin, F., Raisbeck, G., Raynaud, D., Schilt, A., Schwander, J., Selmo, E., Souchez, R., Spahni, R., Stauffer, B., Steffensen, J. P., Stenni, B., Stocker, T. F., Tison, J. L., Werner, M., and Wolff, E. W.: Orbital and Millennial Antarctic Climate Variability over the Past 800,000 Years, Science, 317, 793-796, doi:10.1126/science.1141038, 2007.

Kawamura, K., Parrenin, F., Lisiecki, L., Uemura, R., Vimeux, F., Severinghaus, J. P., Hutterli, M. A., Nakazawa, T., Aoki, S., Jouzel, J., Raymo, M. E., Matsumoto, K., Nakata, H., Motoyama, H., Fujita, S., Goto-Azuma, K., Fujii, Y., and Watanabe, O.: Northern Hemisphere forcing of climatic cycles in Antarctica over the past 360,000 years, Nature, 448, 912-916, doi:10.1038/nature06015, 2007.

Kobashi, T., Ikeda-Fukazawa, T., Suwa, M., Schwander, J., Kameda, T., Lundin, J., Hori, A., Motoyama, H., Döring, M., and Leuenberger, M.: Post-bubble close-off fractionation of gases in polar firn and ice cores: effects of accumulation rate on permeation through overloading pressure, Atmos. Chem. Phys., 15, 13895-13914, doi:10.5194/acp-15-13895-2015, 2015.

Lambert, F., Delmonte, B., Petit, J. R., Bigler, M., Kaufmann, P. R., Hutterli, M. A., Stocker, T. F., Ruth, U., Steffensen, J. P., and Maggi, V.: Dust-climate couplings over the past 800,000 years from the EPICA Dome C ice core, Nature, 452, 616-619, doi:10.1038/nature06763, 2008.

Landais, A., Caillon, N., Severinghaus, J., Jouzel, J., and MassonDelmotte, V.: Analyses isotopiques à haute précision de l'air piégé dans les glaces polaires pour la quantification des variations rapides de température: méthodes et limites, Notes des activités instrumentales de l'IPSL, 39, 2003.

Landais, A., Masson-Delmotte, V., Combourieu Nebout, N., Jouzel, J., Blunier, T., Leuenberger, M., Dahl-Jensen, D., and Johnsen, S.: Millenial scale variations of the isotopic composition of atmospheric oxygen over Marine Isotopic Stage 4, Earth Planet. Sc. Lett., 258, 101-113, doi:10.1016/j.epsl.2007.03.027, 2007.

Landais, A., Dreyfus, G., Capron, E., Masson-Delmotte, V., Sanchez-Goñi, M., Desprat, S., Hoffmann, G., Jouzel, J., Leuenberger, M., and Johnsen, S.: What drives the millennial and or- bital variations of $\delta^{18} O_{\mathrm{atm}}$ ?, Quaternary Sci. Rev., 29, 235-246, doi:10.1016/j.quascirev.2009.07.005, 2010.

Landais, A., Dreyfus, G., Capron, E., Pol, K., Loutre, M. F., Raynaud, D., Lipenkov, V. Y., Arnaud, L., Masson-Delmotte, V., Paillard, D., Jouzel, J., and Leuenberger, M.: Towards orbital dating of the EPICA Dome $\mathrm{C}$ ice core using $\delta \mathrm{O}_{2} / \mathrm{N}_{2}$, Clim. Past, 8, 191-203, doi:10.5194/cp-8-191-2012, 2012.

Landais, A., Dreyfus, G., Capron, E., Jouzel, J., Masson-Delmotte, V., Roche, D., Prie, F., Caillon, N., Chappellaz, J., Leuenberger, M., Lourantou, A., Parrenin, F., Raynaud, D., and Teste, G.: Two-phase change in $\mathrm{CO}_{2}$, Antarctic temperature and global climate during Termination II, Nat. Geosci., 6, 1062-1065, doi:10.1038/ngeo1985, 2013.

Laskar, J., Robutel, P., Joutel, F., Gastineau, M., Correia, A. C. M., and Levrard, B.: A long-term numerical solution for the insolation quantities of the Earth, Astron. Astrophys., 428, 261-285, doi:10.1051/0004-6361:20041335, 2004.

Lefebvre, E., Arnaud, L., Ekaykin, A., Lipenkov, V., Picard, G., and Petit, J.-R.: Snow temperature measurements at Vostok station from an autonomous recording system (TAUTO): preliminary results from the first year operation, Ice and Snow, 4, 138-145, 2012.

Lemieux-Dudon, B., Blayo, E., Petit, J.-R., Waelbroeck, C., Svensson, A., Ritz, C., Barnola, J.-M., Narcisi, B. M., and Parrenin, F.: Consistent dating for Antarctic and Greenland ice cores, Quaternary Sci. Rev., 29, 8-20, doi:10.1016/j.quascirev.2009.11.010, 2010.

Leuenberger, M. C.: Modeling the signal transfer of seawater $\delta^{18} \mathrm{O}$ to the $\delta^{18} \mathrm{O}$ of atmospheric oxygen using a diagnostic box model for the terrestrial and marine biosphere, J. Geophys. Res., 102, 26 841-26 850, doi:10.1029/97JC00160, 1997.

Libois, Q., Picard, G., Arnaud, L., Morin, S., and Brun, E.: Modeling the impact of snow drift on the decameter-scale variability of snow properties on the Antarctic Plateau, J.Geophys. Res.Atmos., 119, 11662-11681, 2014.

Lipenkov, V. Y., Raynaud, D., Loutre, M. F., and Duval, P.: On the potential of coupling air content and $\mathrm{O}_{2} / \mathrm{N}_{2}$ from trapped air for establishing an ice core chronology tuned on local insolation, Quaternary Sci. Rev., 30, 3280-3289, doi:10.1016/j.quascirev.2011.07.013, 2011.

Lisiecki, L. E. and Raymo, M.: A Pliocene-Pleistocene stack of 57 globally distributed benthic $\delta^{18} \mathrm{O}$ records, Paleoceanography, 20, 1003, doi:10.1029/2004PA001071, 2005.

Loulergue, L., Schilt, A., Spahni, R., Masson-Delmotte, V., Blunier, T., Lemieux, B., Barnola, J.-M., Raynaud, D., Stocker, T. F., and Chappellaz, J.: Orbital and millennial-scale features of atmospheric $\mathrm{CH}_{4}$ over the past 800,000 years, Nature, 453, 383-386, doi:10.1038/nature06950, 2008.

Lüthi, D., Le Floch, M., Bereiter, B., Blunier, T., Barnola, J.-M., Siegenthaler, U., Raynaud, D., Jouzel, J., Fischer, H., Kawamura, K., and Stocker, T. F.: High-resolution carbon dioxide concentration record 650,000-800,000 years before present, Nature, 453, 379-382, doi:10.1038/nature06949, 2008.

Malaizé, B., Paillard, D., Jouzel, J., and Raynaud, D.: The Dole effect over the last two glacial-interglacial cycles, J. Geophys. Res., 104, 14199-14208, doi:10.1029/1999JD900116, 1999.

Marzin, C., Kallel, N., Kageyama, M., Duplessy, J.-C., and Braconnot, P.: Glacial fluctuations of the Indian monsoon and their relationship with North Atlantic climate: new data and modelling 
experiments, Clim. Past, 9, 2135-2151, doi:10.5194/cp-9-21352013, 2013.

Masson-Delmotte, V., Stenni, B., Pol, K., Braconnot, P., Cattani, O., Falourd, S., Kageyama, M., Jouzel, J., Landais, A., Minster, B., Barnola, J. M., Chappellaz, J., Krinner, G., Johnsen, S., Röthlisberger, R., Hansen, J., Mikolajewicz, U., and Otto-Bliesner, B.: EPICA Dome C record of glacial and interglacial intensities, Quaternary Sci. Rev., 29, 113-128, doi:10.1016/j.quascirev.2009.09.030, 2010.

Masson-Delmotte, V., Buiron, D., Ekaykin, A., Frezzotti, M., Gallée, H., Jouzel, J., Krinner, G., Landais, A., Motoyama, H., Oerter, H., Pol, K., Pollard, D., Ritz, C., Schlosser, E., Sime, L. C., Sodemann, H., Stenni, B., Uemura, R., and Vimeux, F.: A comparison of the present and last interglacial periods in six Antarctic ice cores, Clim. Past, 7, 397-423, doi:10.5194/cp-7397-2011, 2011.

Meese, D. A., Gow, A. J., Grootes, P., Stuiver, M., Mayewski, P. A., Zielinski, G. A., Ram, M., Taylor, K. C., and Waddington, E. D.: The Accumulation Record from the GISP2 Core as an Indicator of Climate Change Throughout the Holocene, Science, 266, 1680-1682, doi:10.1126/science.266.5191.1680, 1994.

Paillard, D., Labeyrie, L., and Yiou, P.: Macintosh Program performs time-series analysis, EOS Transactions, 77, 379-379, doi:10.1029/96EO00259, 1996.

Parrenin, F., Jouzel, J., Waelbroeck, C., Ritz, C., and Barnola, J.-M.: Dating the Vostok ice core by an inverse method, J. Geophys. Res., 106, 31837-31852, doi:10.1029/2001JD900245, 2001.

Parrenin, F., Rémy, F., Ritz, C., Siegert, M. J., and Jouzel, J.: New modeling of the Vostok ice flow line and implication for the glaciological chronology of the Vostok ice core, J. Geophys. Res.-Atmos., 109, D20102, doi:10.1029/2004JD004561, 2004.

Parrenin, F., Barnola, J.-M., Beer, J., Blunier, T., Castellano, E., Chappellaz, J., Dreyfus, G., Fischer, H., Fujita, S., Jouzel, J., Kawamura, K., Lemieux-Dudon, B., Loulergue, L., MassonDelmotte, V., Narcisi, B., Petit, J.-R., Raisbeck, G., Raynaud, D., Ruth, U., Schwander, J., Severi, M., Spahni, R., Steffensen, J. P., Svensson, A., Udisti, R., Waelbroeck, C., and Wolff, E.: The EDC3 chronology for the EPICA Dome C ice core, Clim. Past, 3, 485-497, doi:10.5194/cp-3-485-2007, 2007.

Parrenin, F., Bazin, L., Capron, E., Landais, A., Lemieux-Dudon, B., and Masson-Delmotte, V.: IceChrono1: a probabilistic model to compute a common and optimal chronology for several ice cores, Geosci. Model Dev., 8, 1473-1492, doi:10.5194/gmd-81473-2015, 2015.

Petit, J. R., Jouzel, J., Raynaud, D., Barkov, N. I., Barnola, J.M., Basile, I., Bender, M., Chappellaz, J., Davis, M., Delaygue, G., Delmotte, M., Kotlyakov, V. M., Legrand, M., Lipenkov, V. Y., Lorius, C., Pépin, L., Ritz, C., Saltzman, E., and Stievenard, M.: Climate and atmospheric history of the past 420,000 years from the Vostok ice core, Antarctica, Nature, 399, 429436, doi:10.1038/20859, 1999.

Picard, G., Domine, F., Krinner, G., Arnaud, L., and Lefebvre, E.: Inhibition of the positive snow-albedo feedback by precipitation in interior Antarctica, Nature Climate Change, 2, 795-798, doi:10.1038/nclimate1590, 2012.

Raynaud, D., Lipenkov, V., Lemieux-Dudon, B., Duval, P., Loutre, M.-F., and Lhomme, N.: The local insolation signature of air content in Antarctic ice. A new step toward an absolute dat- ing of ice records, Earth Planet. Sci. Lett., 261, 337-349, doi:10.1016/j.eps1.2007.06.025, 2007.

Reutenauer, C., Landais, A., Blunier, T., Bréant, C., Kageyama, M., Woillez, M.-N., Risi, C., Mariotti, V., and Braconnot, P.: Quantifying molecular oxygen isotope variations during a Heinrich stadial, Clim. Past, 11, 1527-1551, doi:10.5194/cp-11-1527-2015, 2015.

Schaaf, C. B., Wang, Z., and Strahler, A. H.: Commentary on Wang and Zender - MODIS snow albedo bias at high solar zenith angles relative to theory and to in situ observations in Greenland, Remote Sens. Environ., 115, 1296-1300, doi:10.1016/j.rse.2011.01.002, 2011.

Severinghaus, J. P. and Battle, M. O.: Fractionation of gases in polar ice during bubble close-off: New constraints from firn air Ne, $\mathrm{Kr}$ and Xe observations, Earth Planet. Sc. Lett., 244, 474-500, doi:10.1016/j.eps1.2006.01.032, 2006.

Severinghaus, J. P., Grachev, A., and Battle, M.: Thermal fractionation of air in polar firn by seasonal temperature gradients, Geochem. Geophys. Geosyst., 2, doi:10.1029/2000GC000146, 2001.

Severinghaus, J. P., Beaudette, R., Headly, M. A., Taylor, K., and Brook, E. J.: Oxygen- 18 of $\mathrm{O}_{2}$ Records the Impact of Abrupt Climate Change on the Terrestrial Biosphere, Science, 324, 14311434, doi:10.1126/science.1169473, 2009.

Shackleton, N. J., Hall, M. A., and Vincent, E.: Phase relationships between millennial-scale events 64,000-24,000 years ago, Paleoceanography, 15, 565-569, doi:10.1029/2000PA000513, 2000.

Sime, L. C., Wolff, E. W., Oliver, K. I. C., and Tindall, J. C.: Evidence for warmer interglacials in East Antarctic ice cores, Nature, 462, 342-345, doi:10.1038/nature08564, 2009.

Sowers, T., Bender, M., and Raynaud, D.: Elemental and isotopic composition of occluded $\mathrm{O}_{2}$ and $\mathrm{N}_{2}$ in polar ice, J. Geophys. Res., 94, 5137-5150, doi:10.1029/JD094iD04p05137, 1989.

Spahni, R., Chappellaz, J., Stocker, T. F., Loulergue, L., Hausammann, G., Kawamura, K., Flückiger, J., Schwander, J., Raynaud, D., Masson-Delmotte, V., and Jouzel, J.: Atmospheric Methane and Nitrous Oxide of the Late Pleistocene from Antarctic Ice Cores, Science, 310, 1317-1321, doi:10.1126/science.1120132, 2005.

Stenni, B., Masson-Delmotte, V., Selmo, E., Oerter, H., Meyer, H., Röthlisberger, R., Jouzel, J., Cattani, O., Falourd, S., Fischer, H., Hoffmann, G., Iacumin, P., Johnsen, S. J., Minster, B., and Udisti, R.: The deuterium excess records of EPICA Dome C and Dronning Maud Land ice cores (East Antarctica), Quaternary Sci. Rev., 29, 146-159, doi:10.1016/j.quascirev.2009.10.009, 2010.

Suwa, M. and Bender, M. L.: $\mathrm{O}_{2} / \mathrm{N}_{2}$ ratios of occluded air in the GISP2 ice core, J. Geophys. Res.-Atmos., 113, D11119, doi:10.1029/2007JD009589, 2008a.

Suwa, M. and Bender, M. L.: Chronology of the Vostok ice core constrained by $\mathrm{O}_{2} / \mathrm{N}_{2}$ ratios of occluded air, and its implication for the Vostok climate records, Quaternary Sci. Rev., 27, 10931106, doi:10.1016/j.quascirev.2008.02.017, 2008b.

Svensson, A., Andersen, K. K., Bigler, M., Clausen, H. B., DahlJensen, D., Davies, S. M., Johnsen, S. J., Muscheler, R., Parrenin, F., Rasmussen, S. O., Röthlisberger, R., Seierstad, I., Steffensen, J. P., and Vinther, B. M.: A 60000 year Greenland stratigraphic ice core chronology, Clim. Past, 4, 47-57, doi:10.5194/cp-4-472008, 2008. 
Town, M. S., Waddington, E. D., Walden, V. P., and Warren, S. G.: Temperatures, heating rates and vapour pressures in near-surface snow at the South Pole, J. Glaciol., 54, 487-498, doi:10.3189/002214308785837075, 2008.

Uemura, R., Masson-Delmotte, V., Jouzel, J., Landais, A., Motoyama, H., and Stenni, B.: Ranges of moisture-source temperature estimated from Antarctic ice cores stable isotope records over glacial-interglacial cycles, Clim. Past, 8, 11091125, doi:10.5194/cp-8-1109-2012, 2012.

Veres, D., Bazin, L., Landais, A., Toyé Mahamadou Kele, H., Lemieux-Dudon, B., Parrenin, F., Martinerie, P., Blayo, E., Blunier, T., Capron, E., Chappellaz, J., Rasmussen, S. O., Severi, M., Svensson, A., Vinther, B., and Wolff, E. W.: The Antarctic ice core chronology (AICC2012): an optimized multi-parameter and multi-site dating approach for the last 120 thousand years, Clim. Past, 9, 1733-1748, doi:10.5194/cp-9-1733-2013, 2013.

Waelbroeck, C., Frank, N., Jouzel, J., Parrenin, F., MassonDelmotte, V., and Genty, D.: Transferring radiometric dating of the last interglacial sea level high stand to marine and ice core records, Earth Planet. Sci. Lett., 265, 183-194, doi:10.1016/j.eps1.2007.10.006, 2008.
Wang, Y., Cheng, H., Edwards, R. L., Kong, X., Shao, X., Chen, S., Wu, J., Jiang, X., Wang, X., and An, Z.: Millennial- and orbitalscale changes in the East Asian monsoon over the past 224,000 years, Nature, 451, 1090-1093, doi:10.1038/nature06692, 2008.

Wang, Y. J., Cheng, H., Edwards, R. L., An, Z. S., Wu, J. Y., Shen, C.-C., and Dorale, J. A.: A High-Resolution Absolute-Dated Late Pleistocene Monsoon Record from Hulu Cave, China, Science, 294, 2345-2348, doi:10.1126/science.1064618, 2001.

Witrant, E., Martinerie, P., Hogan, C., Laube, J. C., Kawamura, K., Capron, E., Montzka, S. A., Dlugokencky, E. J., Etheridge, D., Blunier, T., and Sturges, W. T.: A new multi-gas constrained model of trace gas non-homogeneous transport in firn: evaluation and behaviour at eleven polar sites, Atmos. Chem. Phys., 12, 11465-11483, doi:10.5194/acp-12-11465-2012, 2012. 